DOE/NASA CONTRACTOR REPORT

DOE/NASA CR-150770

\title{
SOLAR HEATING AND COOLING SYSTEMS DESIGN AND DEVELOPMENT (Quarterly Report No. 4)
}

Prepared by

Honeywell, Inc.

2600 Ridgway Parkway

Minneapolis, Minnesota 55413

Under Contract NAS8-32093 with

National Aeronautics and Space Administration

George C. Marshall Space Flight Center, Alabama 35812

For the Department of Energy

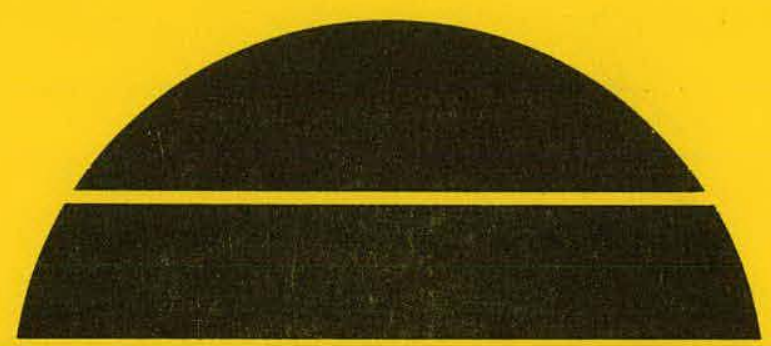

\section{U.S. Department of Energy}




\section{DISCLAIMER}

This report was prepared as an account of work sponsored by an agency of the United States Government. Neither the United States Government nor any agency Thereof, nor any of their employees, makes any warranty, express or implied, or assumes any legal liability or responsibility for the accuracy, completeness, or usefulness of any information, apparatus, product, or process disclosed, or represents that its use would not infringe privately owned rights. Reference herein to any specific commercial product, process, or service by trade name, trademark, manufacturer, or otherwise does not necessarily constitute or imply its endorsement, recommendation, or favoring by the United States Government or any agency thereof. The views and opinions of authors expressed herein do not necessarily state or reflect those of the United States Government or any agency thereof. 


\section{DISCLAIMER}

Portions of this document may be illegible in electronic image products. Images are produced from the best available original document. 
NOTICE

Th1s report was prepared to document work sponsored by the United States Government. Nelther the Unfted States nor 1ts agents the United States Department of Energy, the Un1ted States National Aeronautics and Space Administration, nor any federal employees, nor any of their contractors, subcontractors or the1r employees, make any warranty, express or implled, or assume any legal liabllity or responsibllity for the accuracy, completiness, or usefulness of any information, apparatus, product or process disclosed, or represent that its use would not infinge priyately owned rights. 


1. REPORT NO.
DOE/NASA CR-150770

4. TITLE AND SUBTITLE

Solar Heating and Cooling Systems Design and Development (Quarterly Report No. 4)

7. AUTHOR(S)

9. PERFORMING ORGANIZATION NAME AND AODRESS

Honeywell, Inc.

2600 Ridgway Parkway

Minneapolis, Minnesota 55413

12. SPONSORING AGENCY NAME AND ADORESS

National Aeronautics and Space Administration

Washington, D. C. 20546

2. GOVERNMENT ACCESSION NO.
3. RECIPIENT'S CATALOG NO.

5. REPORT DATE

July 1977

6. PERFORMING ORGANIZATION CODE

8. PERFORMING ORGANIZATION REPORT \#

10. WORK UNIT, NO.

11. CONTRACT OR GRANT NO. NAS8-32093

13. TYPE OF REPORI \& PERIOD COVERED

Contractor Report

April 1, 1977 - June 30, 1977

14. SPONSORING AGENCY CODE

15. SUPPLEMENTARY NOTES

This work was done under the technical management of Mr. Al Krupnick, George C. Marshäll Späce Flight Center, Alabama.

16. ABSTRACT

Honeywell is developing twelve prototype solar heating/cooling systems, six heating and six heating and cooling systems, two each for single fámily; multi-family, and commercial applications." This document contains the schedules and technical discussions, along with illustrations on the progress made from April 1, 1977 through June 30, 1977.

Cost information has been removed from this report.

19. SECURITY CLASSIF. (UI thte roport)

Unclassified
20. SECURITY CLASSIF. (ot this pago)

Unclassified
21. NO. OF PAGES

87 ,
NTIS 


\section{FOREWORD}

-Honeywell was awarded Contract NAS8-32093 by the George C. Marshall Space Flight Center effective 9 July 1976.

The program calls for the Development and deljvery of eight (was 12) prototype solar heating and cooling systems for installation and operational test. Two (was 6) heating and six heating and cooling units will be delivered for single-family residences (SFR), multiple-family residences (MFR) and commercial applications:

Lennox Industries, Harshalltown, Iova, and Barber Nichols Engineering Company, Arvada, Colorado, are supporting Honeywell in subcontractor roles.

This document describes the progress of the program during the fourth program quarter (1 April 1977 to 30 June 1977). It is submitted to MSFC for information per DR500 Item 10. 


\section{CONTENTS}

\begin{tabular}{|c|c|c|c|}
\hline \multirow{2}{*}{$\begin{array}{l}\text { SECTION } 1 \\
\text { SECTION } 2\end{array}$} & SUMMARY & & $1-1$ \\
\hline & (This section has been deleted) & & $2-1$ \\
\hline SECTION 3 & SCHEDULES & & $3-1$ \\
\hline SECTION 4 & TECHNICAL STATUS & & $4-1$ \\
\hline & Summary & & $4-1$ \\
\hline$\because$ & Analy sis and Integration & & $4-1$ \\
\hline & William $\mathrm{O}^{\prime} \mathrm{B}$ rien & & $4-2$ \\
\hline & New Castle, Pennsylvania & & $4-8$ \\
\hline & University of Kansas; Lawrence, Kansas & & $4-11$ \\
\hline$\because "$ & Collector & & $4-12$ \\
\hline 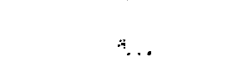 & Collector Field Selection & , & $4-12$ \\
\hline & Collector A rray Design $\quad \because$ & $\because$ & $4-12$ \\
\hline$\therefore:$ & Collector Field Summary & $\therefore$ & $4-17$ \\
\hline & Collector Qualification Tests & & $4-19$ \\
\hline & Space Heating and Auxiliary Heating & & $4-19$ \\
\hline$\therefore$ & Work Äccomplished & $\therefore$ & $4-19$ \\
\hline$\cdots$ & Energy Transport Subsystem & & $4-35$ \\
\hline$:$ & Control Subsystem & : & $4-46$ \\
\hline$\because$ & Cooling $\ldots$ & & $4-47$ \\
\hline SECIION 5 & SITE ACTIVITY & $\therefore$ & $5-1$ \\
\hline . & SFR Hcating - Stillwater, Minnesota & $\vdots$ & $5-1$ \\
\hline 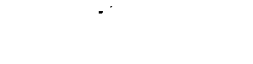 & SFR Heating - Newcastle, Pennsylvania, & Site & $.5-5$ \\
\hline $\begin{aligned} \ddots & \vdots \\
\vdots & \end{aligned}$ & $\begin{array}{l}: \text { SFR Heating ańd Cooling - Law rence; } \\
\therefore \quad \text { Kansas (KU) }\end{array}$ & : & $5-6$ \\
\hline SECIION 6 & DATA SUBMISSIONS & & $6-1$ \\
\hline
\end{tabular}




\section{LIST OF FIGURES}

3-1 Single Frimily Residence--Heating only-Stillwater, Minn. 3-2

3-2 Single Family Residence Heating Only - New Castle, PA 3-3

3-3 : Single Family Residence Heating and Cooling Site - 3-4 Sacramento, California

3-4. Single Family Residence Heating and Cooling Site - 3-5 Jacksonville, Florida

3-5 Kansas University Multiple Family Residence 3-6

3-6 :, Multiple Family Residence Heating and Cooling - 3-7 Columbus, Geogia

3-7 Commercial Heating and Cooling Site Number 1 3-8

3-8 Commercial Heating and Cooling Site Number 2 3-9

4-1 "Effect of Collector Area (Modules) on Space Heating 4-4 Contribution

4-2 Solar/Air Source Heat Pump System . 4-9

4-3 Schematic of Collector Field . 4-13

4-4 Minimunı Heáder Size for Series-Parallel Collectors Array 4-14

4-5. Minimum Header Size for Series-Parallel Collector Array 4-15

4-6 Flow Variation for Series-Parallel Collector Array 4-16

4-7 Flow Variation for Series-Parallel Collector Array ' . ' 4-16

4-8 Pressure Drop Across Stacked Collectors in Series 4-18

4-9 Lennox Unit Showing Controls 4-21

4-10 Modified Wiring in Lennox Unit $\quad$ 4-22 
LIST OF FIGURES (Concluded)

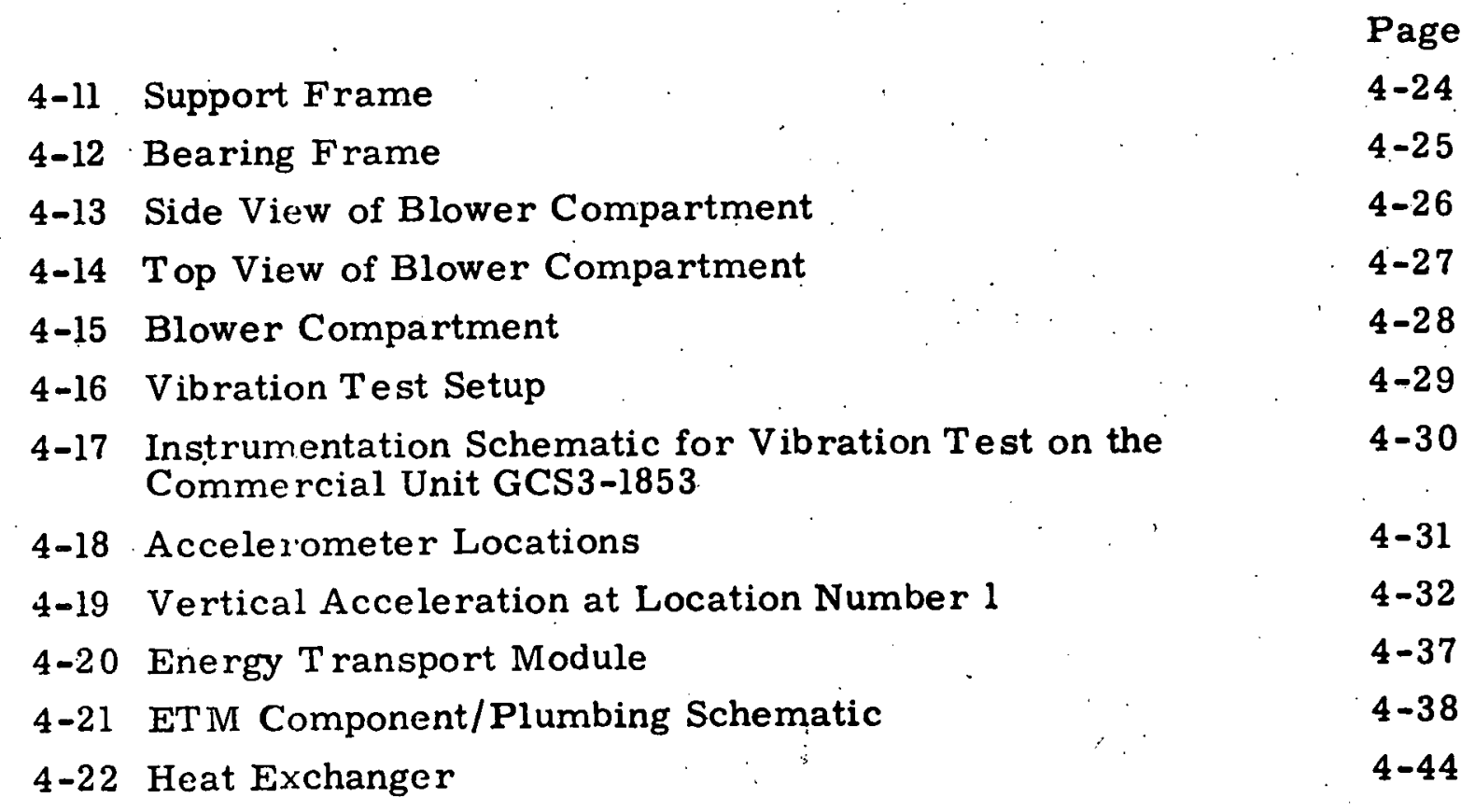




\section{SECTION I}

SUMMARY

The Solar Heating and Cooling Development Program is six months behind the baseline program both in costs and schedule. This delay is due to the delay in identification of operational sites by NASA. A fiscal replan was prepared and submitted to NASA/MSFC dated April 16, 1977.

As of June 30,1977 , the program costs are underspent by $16 \%$. This variance is due to the delay in identifying the remaining sites. There is zero variance between the work accomplished and the cost incurred. 


$$
2-1
$$

SECTION 2

COSTS

This section has been deleted. 
SECTION 3

SCHEDULES

Figures 3-1 through 3-8 show schedules for all deliverable hardware systems. The schedules for SFR H/C, MFR H/C and Commercial $\mathrm{H} / \mathrm{C}$ are based on optimistic time estimates for each activity. Any problem could easily put the program in a late delivery situation.

The lack of specific site data would be the primary deterrent to achieving these schedules. A critical site date is shown on each of the five schedules where sites have not been identified. If site selections have not been made by these dates, delivery of that hardware would undoubtedly be delayed beyond the contractual date.

The current status for systems that have sites selected is shown as of June 30, 1977. 


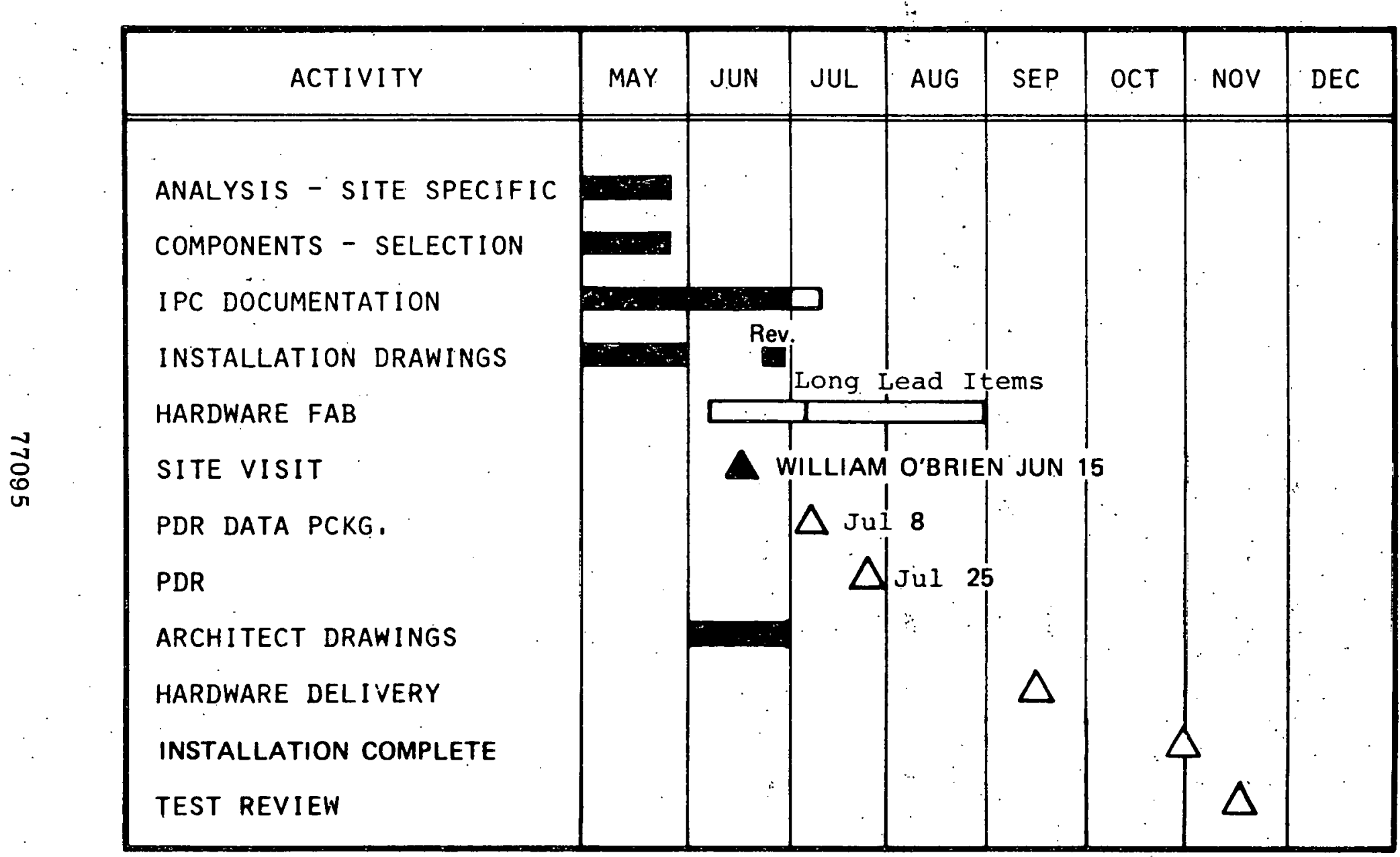

REVISED $7-15-77$

Figure 3-1. Single Family Residence--Heating only - Stillwater, Minnesota 


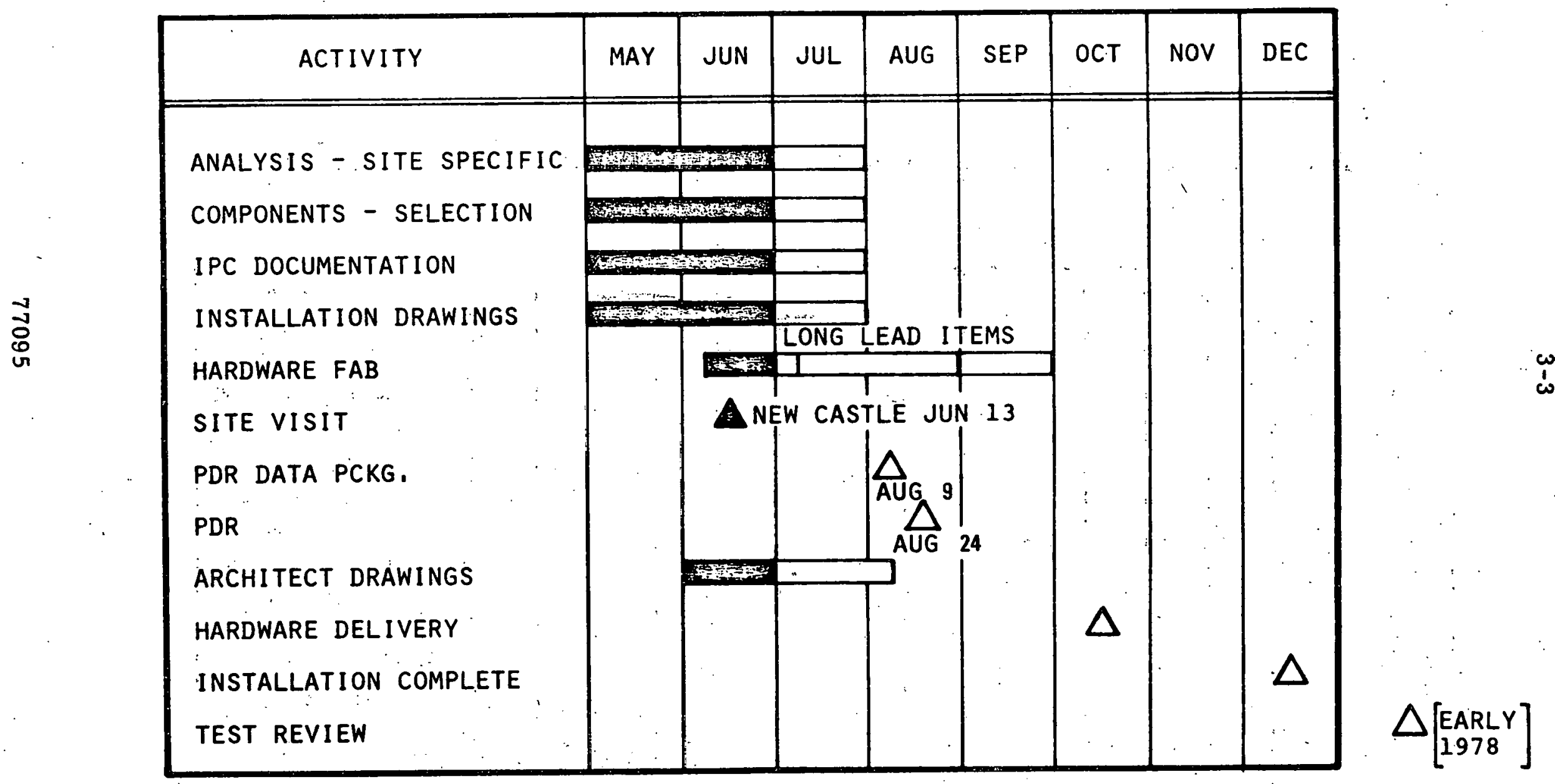

REVISED 7-15-77

Figure 3-2. Single Family Residence--Heating Only - New Castle, Pennsylvania 


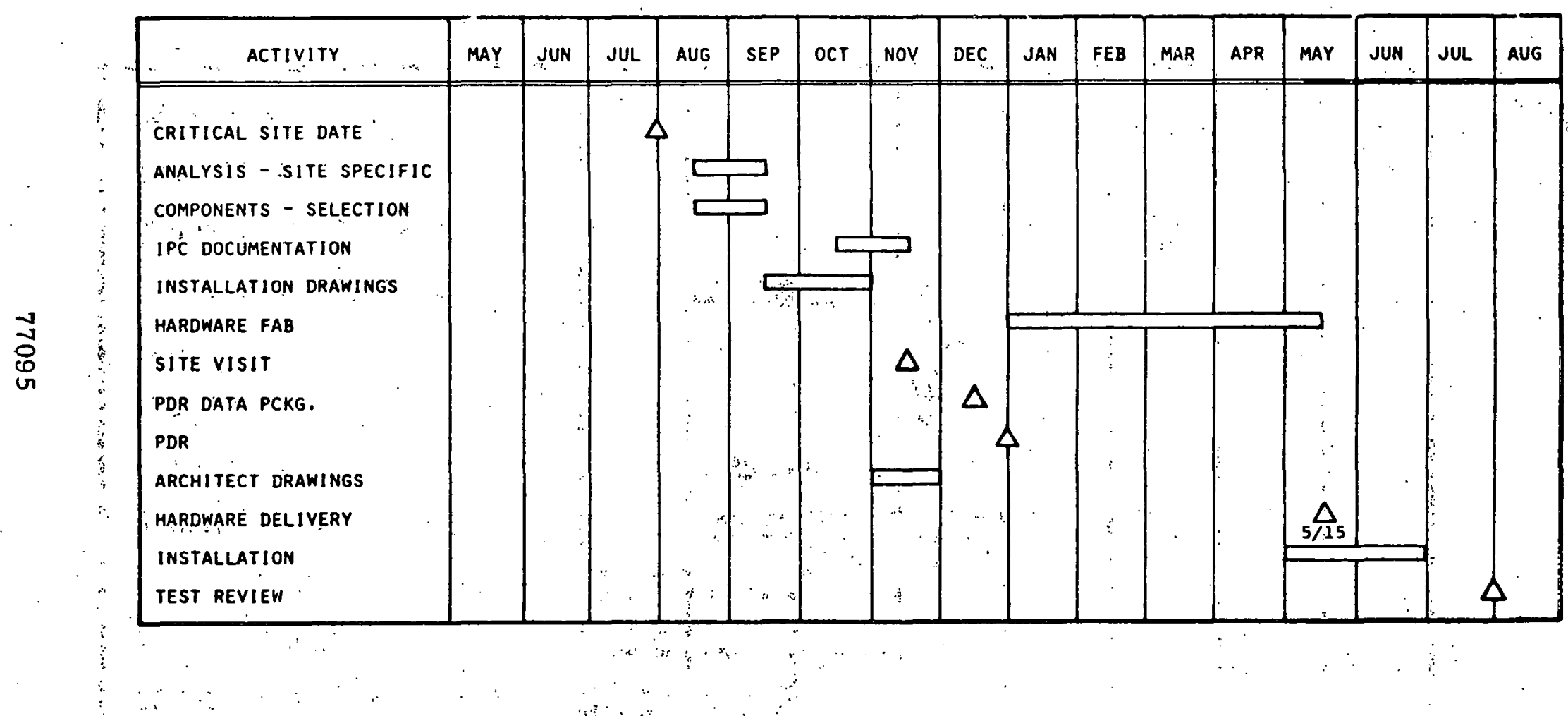

Figure 3-3. Single Family Residence Heating and Cooling Site--Sacramento, California 


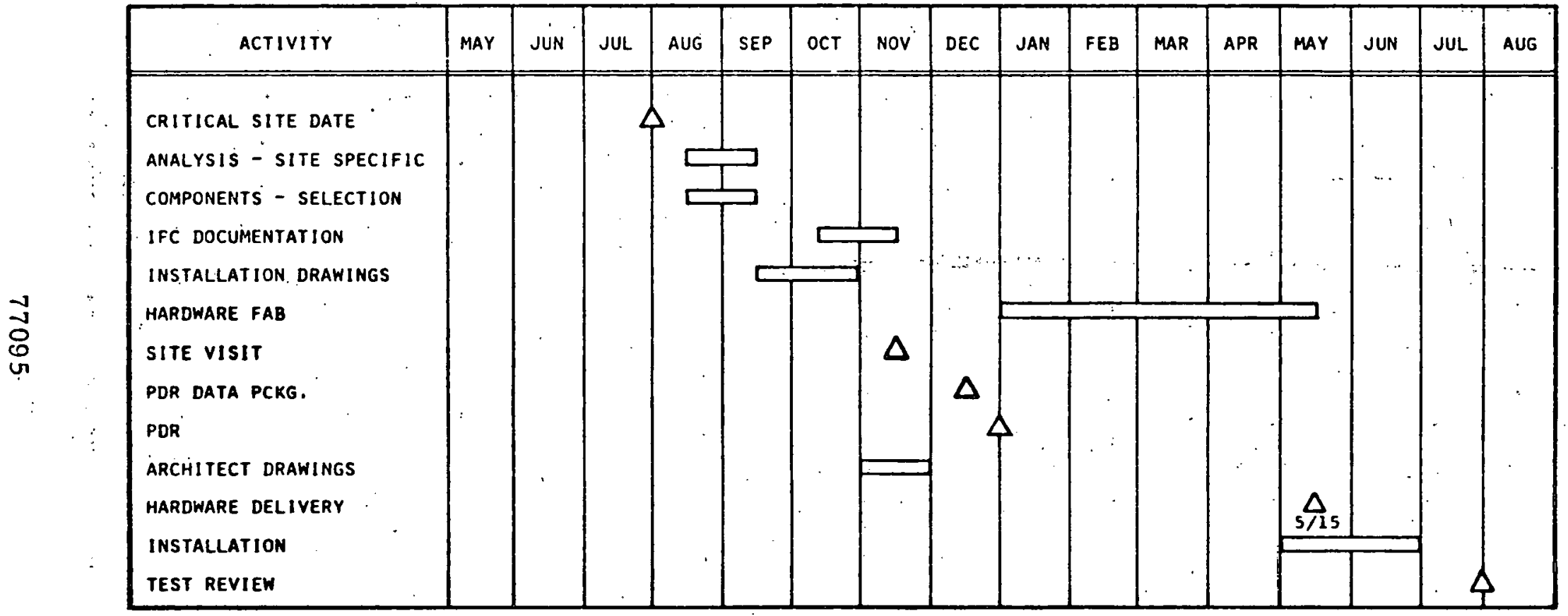

Figure 3-4. Single Family Residence Heating and Cooling Site--Jacksonville, Florida 


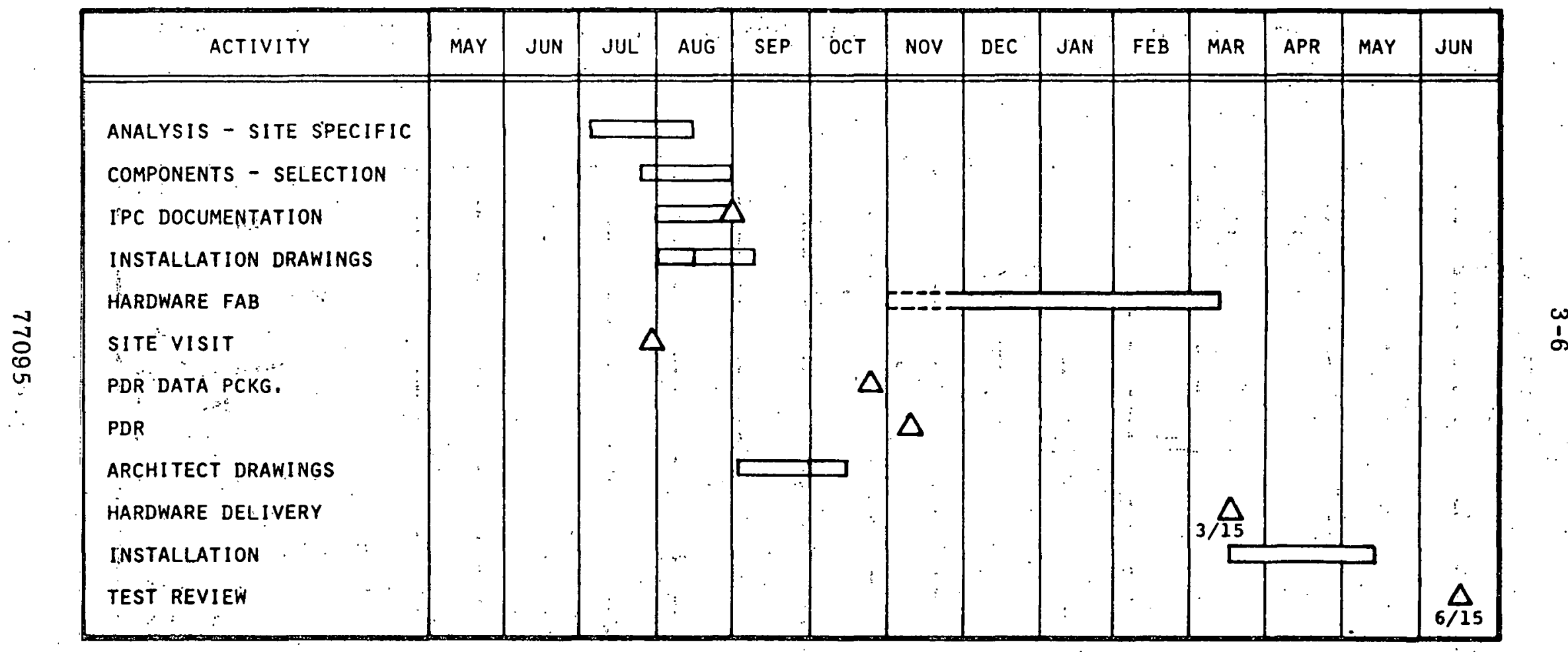

Figure $3-5$. Kansas University Multiple Family Residence 


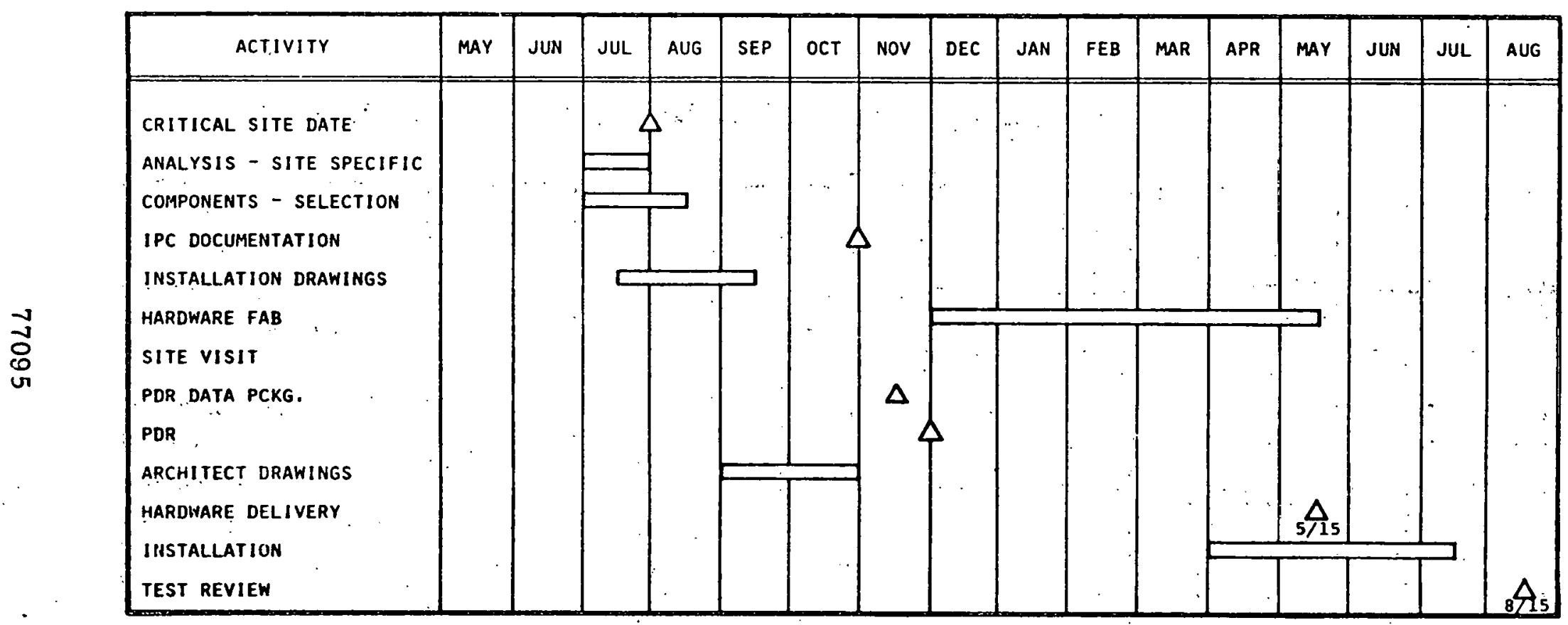

Figure 3-6. Multiple Family Residence Heating and Cooling--Columbus, Georgia 


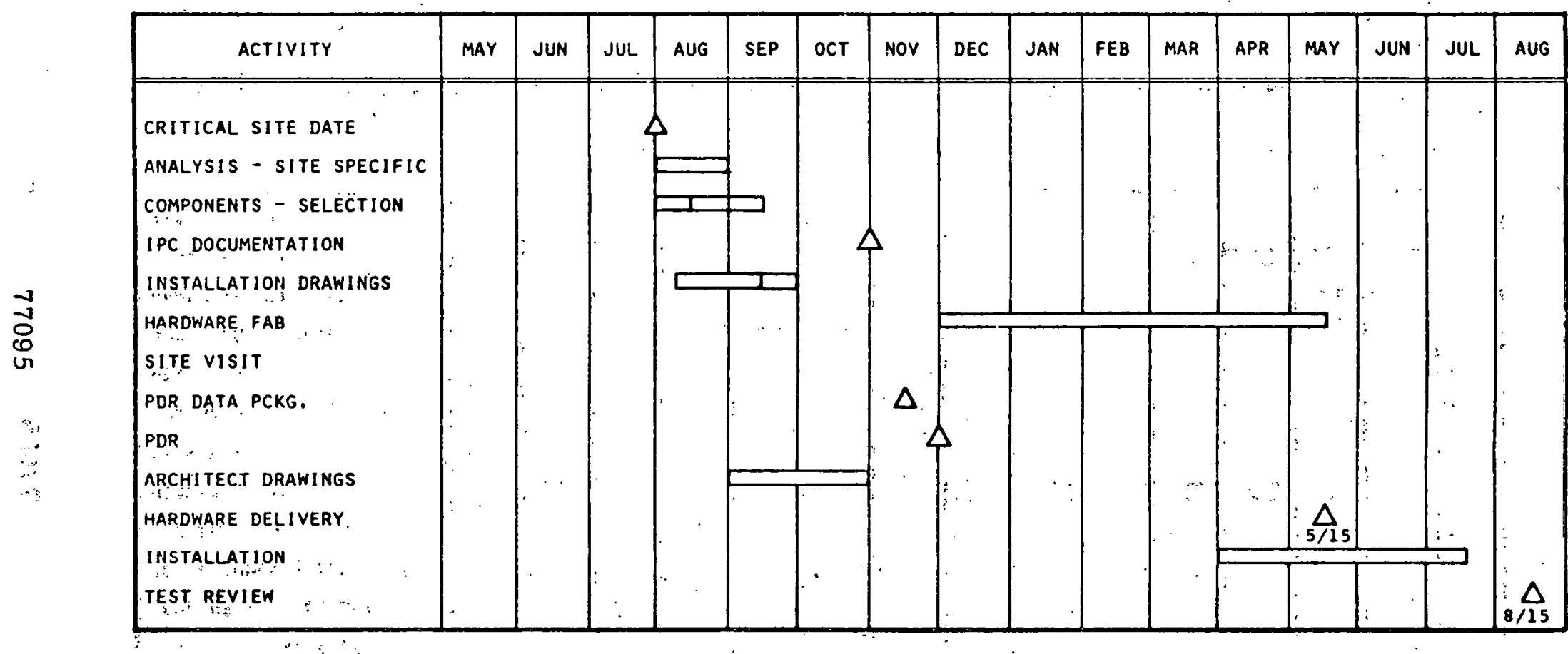

Figure 3-7. Commercial Heating and Cooling Site Number 1

REVISED 7-15-77 


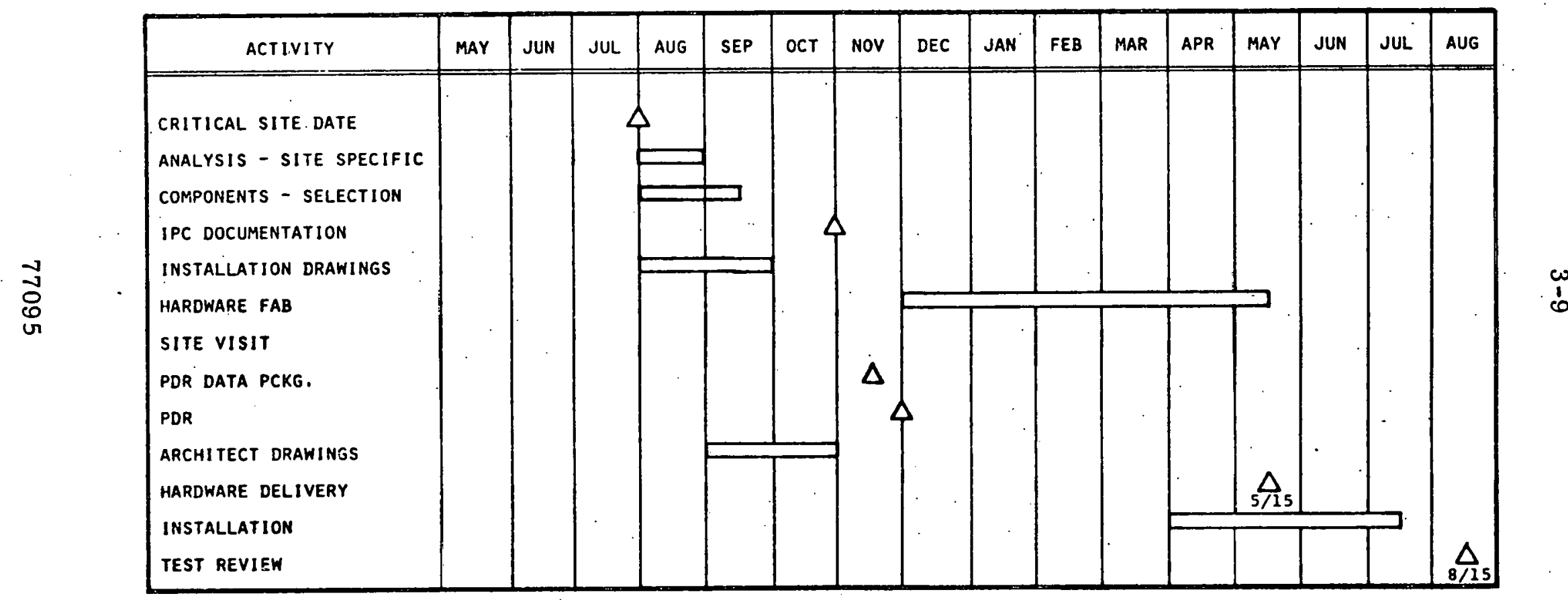

Figure 3-8. Commercial Heating and Cooling Site Number 2 


\section{SECTION 4}

TECHNICAL STATUS

\section{SUMMARY}

The principle activity during this quarter has been the finalization of the system and its components for the single-family heating site at Stillwater, Minnesota. Delivery of this system is scheduled for late in the next quarter. The design effort on the single-family heating site at New Castle, Pennsylvania is in progress and will be completed during the next quarter. Since only three of the eight operational sites have been authorized by NASA, installation design work on the other five sites is not being done. If this activity does not start by August 1, the May 15, 1977, delivery schedule cannot be met.

The Cooling subsystems (3-ton and 25-ton) are progressing on schedule. Most hardware components are being either procured or fabricated with assembly scheduled to start during the next quarter.

\section{ANALYSIS AND INTEGRATION}

Site specific simulation studies have been conducted on the three sites delineated at this time. The three sites are the William O'Brien single-family residence heating only, New Castle, Pennsylvania, single-family residence heating only, and the University of Kansas multi-family residence heating and cooling. The William O'Brien analysis is complete and will be discussed in detail here. The New Castle and University of Kansas analysis are in a preliminary stage and will be discussed in less detail. 
William O'Brien

A computer simulation model for the William O'Brien solar heating site was analyzed, and results were obtained such that component optimization could be made. The system was analyzed for years 1957 and 1958 with final results based on the year 1958. Also the energy conservation improvements described earlier were implemented in the simulation model.

The system tradeoff study consisted of checking the effect on space heating and DHW contribution by solar energy for variations in the following parameters:

1. Collector area

2. Storage tank size

3. Storage tank setpoint temperature

4. Collector-side heat exchanger and solar heating coil effectiveness

5. Collector loop flow rate

6. DHW solar coil in storage tank. Not all parameters were check individually. Previous analyses had shown that small gains could be expected by increasing the individual heat exchanger effectiveness above .6 and that the load-side heat exchanger had a larger effect on increasing system performance. Also, from previous analyses, system flow rates were set to approximately $12 \mathrm{gpm}$ in the collector loop and $8 \mathrm{gpm}$ in both the direct heating and heating from storage loops. Of the three flows, the variation of collector loop flow rate has the dominant effect on increasing system performance. Therefore, only the collector loop flow variation was considered for optimization analysis. 
Results of system component tradeoff analysis for total system optimization are summarized in Table 4-1. The effect of solar base year selection can be noted. The performance of the initially proposed solar heating system for the year 1957 was $44.4 \%(\# 1)$ and $46.5 \%$ (\#6) for the year 1958. This was entirely due to 1958 being a better solar year. The selection of a base year for solar energy demonstration can be a factior. It is desirable to naturally have high solar incidence. However, it is just as important to have a good load heating season to reflect actual conditions that may be encountered.

The effect of varying all of the listed parameters except collector area is shown in simulation runs \#2 to \#5. Simulation run \#2 shows the unfavorable effect of having no DHW coil inside the storage tank. Simulation runs \#3, \#4, and \#5 show. only a modest gain. in total solar contribution for large changes in all parameters except collector area. These results indicate the need for more collector modules for solar energy to provide a reasonable portion of the house total energy load.

Simulation runs \#6, \# 7, and \#8 show the effect of increasing collector area from $504 \mathrm{sq}$. ft. (28 modules) to $594 \mathrm{sq}$. ft. (33 modules) to $648 \mathrm{sq}$. ft. (36 modules). The benefit is reflected mainly by the improvement in solar space heating contribution, and this is shown in Figure 4-1. Although the results indicate an advantage of having $648 \mathrm{sq}$. ft. of collector area, site space limitations dictated that a maximum of 33 collector modules can be installed.

Due to the space limitation imposed on the collector surface area, additional solar benefits were sought elsewhere. Simulation runs \#9, \#10, and \#11 show 


\section{EFFECT OF COLLECTOR AREA (MODULES)}

ON SPACE HEATING CONTRIBUTION

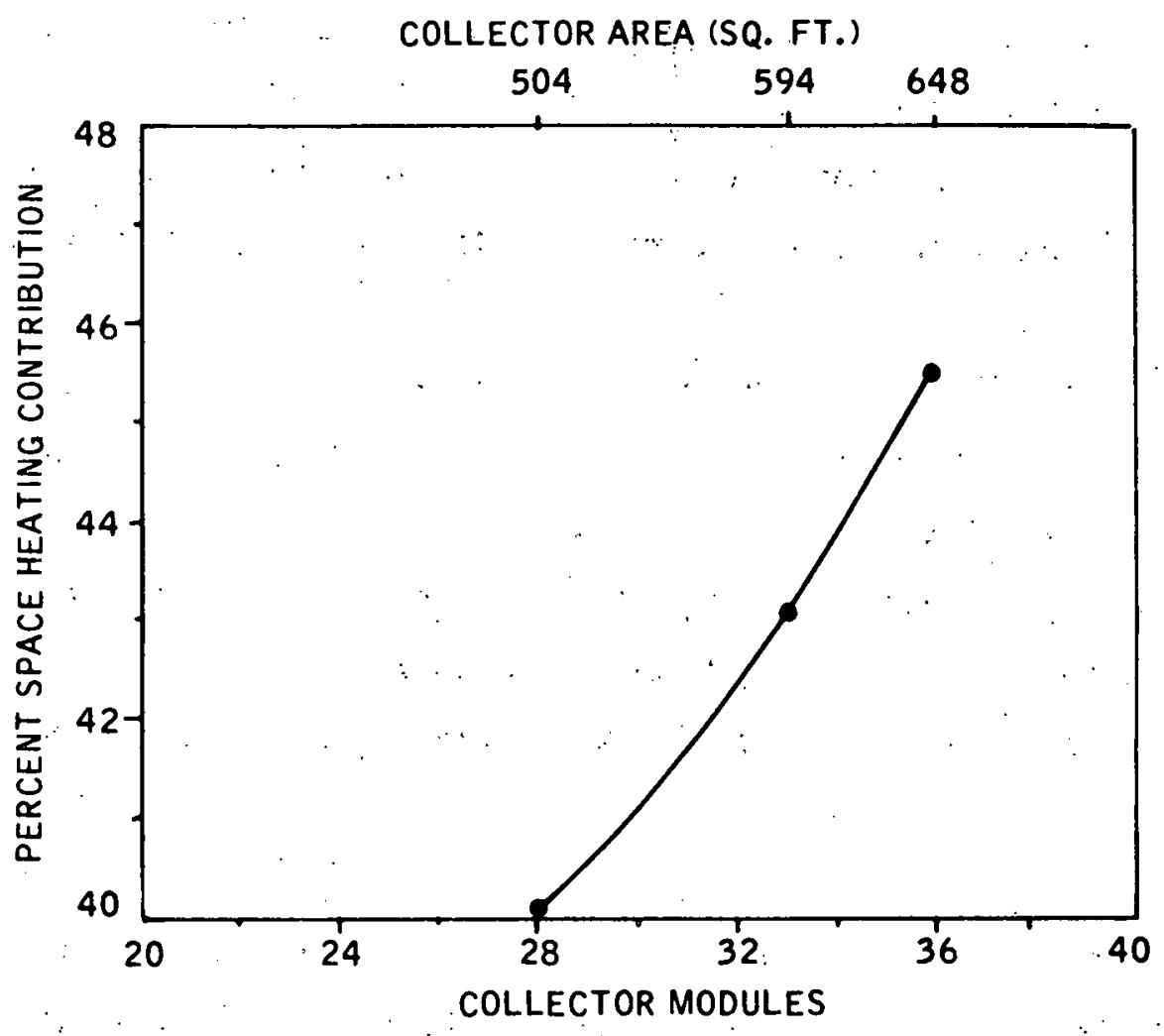

FIGURE 4-1. Effect Of Collector Area (Modules) On Space Heating Contribution 
TABLE 4-1. Wm. O' Brien Site Trade -Studies Summary

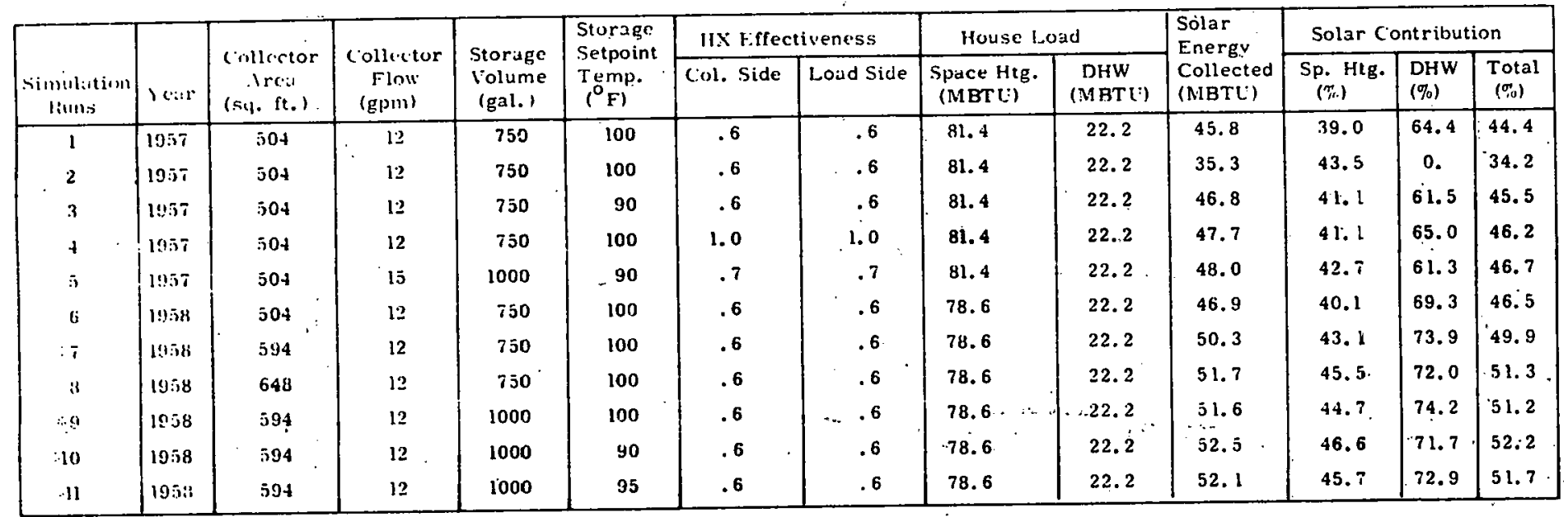

Reisults with energy conservation modifications added to site and new DHW coil in storage tank. 
the gain in solar contribution by increasing the storage tank size to 1000 gallons capacity and decreasing the storage setpoint temperature for space heating from storage. Based on these results, a 1000-gallon storage tank size has been selected for the solar heating system. The solar gain here is due to the large number of hours spent in the heating-from-storage mode, and therefore, a larger storage tank size is beneficial.

The improvements in solar contribution due to a decrease in storage setpoint temperature are given in Table 4-2. Tables 4-3 and 4-4 summarize the yearly power expenditures for the heating site as a function of storage tank setpoint. temperature.

By going to a $90^{\circ} \mathrm{F}$ setpoint temperature, an additional $0.9 \mathrm{MBTU} \mathrm{M}^{-1}$ of energy are gained. This would amount to approximately $\$ 2$ in fuel value. However, an additional $106 \mathrm{KW}-\mathrm{HR}$ of electricity are expended at a cost of approximately $\$ 4.50$. Therefore, no economic advantage is gained in reducing the setpoint.

Based on simulation results and power consumption estimates for the solar heating system, the following design conditions are recommended.for solar system components:

- Collector area of 594 sq. ft.

- Storage tank. size of 1000 gallons

- Storage tank setpoint temperature of $100^{\circ} \mathrm{F}$

- Collector-side heat exchanger effectiveness of approximately 0.6.

- Collector loop flow rate of $12 \mathrm{gpm}$. 
TABLE 4-2 EFFECT OF STORAGE SET POINT TEMPERATURE ON THE PERFORMANCE OF SOLAR HEATING SY ST EM

\begin{tabular}{|c|c|c|c|c|c|c|}
\hline \multirow{2}{*}{$\begin{array}{l}\text { Storage } \\
\text { Setpoint } \\
\left.\text { Temp. ( }{ }^{\circ} \mathrm{F}\right)\end{array}$} & \multirow{2}{*}{$\begin{array}{c}\text { Space } \\
\text { Htg. Load } \\
\text { (MBTU) } \\
\end{array}$} & \multirow{2}{*}{$\begin{array}{c}\text { DHW } \\
\text { Load } \\
\text { (MBTU) } \\
\end{array}$} & \multicolumn{2}{|c|}{ Solar Contribution } & \multirow[b]{2}{*}{$\begin{array}{l}\text { Total } \\
\text { (MBTU) }\end{array}$} & \multirow{2}{*}{$\begin{array}{c}\text { Solar } \\
\text { Improvement } \\
\text { (MBTU) } \\
\end{array}$} \\
\hline & & & $\begin{array}{c}\text { Space Htg. } \\
\text { (MBTU) }\end{array}$ & $\begin{array}{c}\text { DHW } \\
\text { (MBTU) } \\
\end{array}$ & & \\
\hline 100 & 78.6 & 22.2 & 35.1 & 16.5 & 51.6 & - \\
\hline 95 & 78.6 & 22.2 & 35.9 & 16.2 & 52.1 & .5 \\
\hline 90 & 78.6 & 22.2 & 36.6 & 15.9 & 52.5 & .9 \\
\hline
\end{tabular}

TABLE 4-3' WM. 'O' BRIEN SITE POWER EXPENDITURES FOR DIFFERENT MODE S OF OPERATION

\begin{tabular}{|c|c|c|c|c|c|c|c|c|}
\hline \multirow[b]{2}{*}{ Mode } & \multirow{2}{*}{ Operation } & \multirow[b]{2}{*}{$\mathrm{KW} /$ Mode } & \multicolumn{2}{|c|}{$100^{\circ} \mathrm{F}$} & \multicolumn{2}{|c|}{$95^{\circ} \mathrm{F}$} & \multicolumn{2}{|c|}{$90^{\circ} \mathrm{F}$} \\
\hline & & & Hours & KW-HRS & Hours & KW-HRS & Hours & KW-HRS \\
\hline 1 & Idle : & .048 & 5630 & 271 & 5564 & 268 & 5492 & 264 \\
\hline 2 & Direct Heating & .956 & 254 & 243 & 254 & 243 & 253 & 243 \\
\hline 3 & Htg From Storago & .726 & 699 & 508 & 784 & 570 & 892 & 648 \\
\hline 4 & Charge Storage & .486 & 925 & 450 & 928 & 451 & 928 & 451 \\
\hline 5 & Purge & .482 & 723 & 349 & 721 & 348 & 712 & 344 \\
\hline 8 & Aux. Heating & .518 & 478 & 248 & 459 & 238 & 433 & 225 \\
\hline
\end{tabular}

TABLE 44 WM. O! BRIEN SITE YEARLY ENERGY SUMMARY

\begin{tabular}{|c|c|c|c|}
\hline $\begin{array}{l}\text { Storage, } \\
\text { Setpoint } \\
\text { Temp. ( }{ }^{\circ} \text { F) }\end{array}$ & $\begin{array}{c}\text { System Power } \\
\text { Consumption } \\
\text { (KW-HRS) } \\
\end{array}$ & $\begin{array}{l}\text { Net Solar } \\
\text { Contribution } \\
\text { (M.BT U) }\end{array}$ & $\begin{array}{l}\text { Power Consump. } \\
\text { Difference } \\
\text { (KW-HR) }\end{array}$ \\
\hline 100 & 2069 & 51.6 & - \\
\hline 95 & 2118 & 52.1 & 49 \\
\hline 90 & 2175 & 52.5 & 106 \\
\hline
\end{tabular}


New Castle, Pennsylvania

The New Castle single-family residence heating only site will utilize an air source heat pump in parallel with the solar system and an electric resistance heater as the auxiliary energy source. A system schematic is shown in Figure 4-2.

The New Castle house will be new construction with preliminary load data supplied by the architect as shown in Table 4-5.

The heat pump modeled was an air source type with a nominal high temperature heating capacity of $31,000 \mathrm{Btu} / \mathrm{Hr}$ with a corresponding COP of 2.7. The heat pump heat output and COP-versus-ambient air temperature are the inputs to the auxiliary energy section of the simulation model. The control hierarchy is similar to the William O'Brien heating only scheme. If solar energy is available and load is required, direct solar heating occurs. If direct solar energy is not available but there is sufficient energy available from thermal storage and load is required, heating from thermal storage occurs. If none of the above solar inputs is available and heating load is still required, the auxiliary energy source will be used. In the New Castle system, auxiliary energy will first be supplied by the air source heat pump if the ambient temperature is above some lower limit of a COP equal to approximately 1. 0 . If the heat output of the heat pump is insufficient to meet the load, an electric resistance heater will operate simultaneously with the heat pump.

Preliminary simulation results are shown in Table 4-6. Further study is underway with improved load model parameters and heat pump selection and characteristics. 


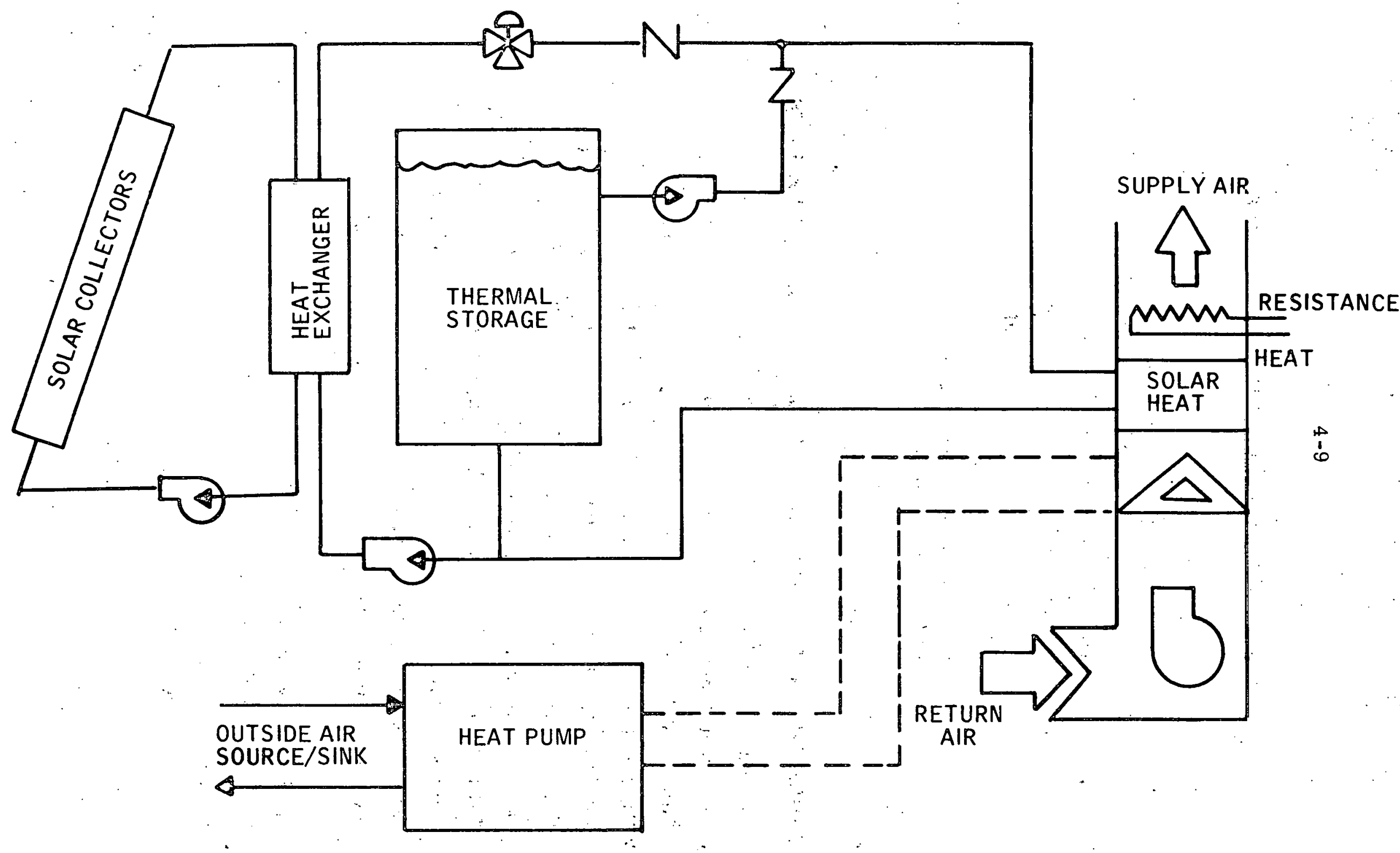

FIGURE 4-2. Solar/Air Source Heat Pump System 
TABI. E 4-5. NEW. CASTLE LOAD PARAMETERS

$\begin{array}{lcc} & \mathrm{U} & { }^{\mathrm{A}} \\ & \mathrm{Btu} / \mathrm{hr} \mathrm{ft}{ }^{20} \mathrm{~F} & \mathrm{ft}^{2} \\ \text { Roof } & 0.037 & 1000 \\ \text { Walls } & 0.04 & 1820 \\ \text { Floor } & 0.05 & 850 \\ \text { Windows } & 0.56 & 395 \\ & & \\ \text { Overall UA }=374 \mathrm{Btu} / \mathrm{Hr}^{\circ} \mathrm{F} \\ \text { Infiltration }=150 \mathrm{cfm}\end{array}$

TABLE 4-6. NEW CASTLE HEAT PUMP SIMULATION RESULTS

$\begin{array}{llll}\text { Collector Area }^{1} & 504 & 396 & 504 \\ \text { Collector Flow Rate }^{2} & 12 & 9.4 & 14.5 \\ \text { Storage Volume }^{3} & 750 & 750 & 1000 \\ \text { Heating Load }^{4} & 56.1 \times 10^{6} & 56.1 \times 10^{6} & 56.1 \times 10^{6} \\ \text { Hot Water Load } 4 & 21.0 \times 10^{6} & 21.0 \times 10^{6} & 21.0 \times 10^{6} \\ \text { Heat Pump Output } 4 & 28.0 \times 10^{6} & 29.9 \times 10^{6} & 26.1 \times 10^{6} \\ \text { Heat Pump Input } 4 & 14.5 \times 10^{6} & 15.5 \times 10^{6} & 13.6 \times 10^{6} \\ \text { Resistance Heat } 4 & 2.9 \times 10^{6} & 3.0 \times 10^{6} & 2.9 \times 10^{6} \\ \text { \% Solar Heating } & 44.9 & 41.3 & 48.5 \\ \text { \% Hot Water Heating } & 66.2 & 62.7 & 66.1 \\ \text { Average Annual COP } & 1.93 & 1.93 & 1.92\end{array}$

1. Expressed in $\mathrm{ft}^{2}$

2. Expressed in gal $/ \mathrm{min}$

$\therefore$ 3. Expressed in gal

4. Expressed in Btu 


\section{University of Kansas; Lawrence, Kansas}

The University of Kansas multi-family residence heating and cooling analysis is in preliminary stage. The building is a 12 -unit married student housing. Results of simulations with a 25 -ton Rankine engine cooling system is shown in Table 4-7.

Further study is underway to improve load calculations and Rankine engine modeling: Studies are underway to determine system performance for various collector areas, storage tank volume, flow rate and collector tilt.

TABLE 4-7. UNIVERSITY OF KANSAS MULTI-FAMILY RESIDENCE HEATING AND COOLING SIMULATION RESULTS

$\begin{array}{ll}\text { Collector Area } & 6120 \mathrm{ft}^{2} \\ \text { Storage volume } & 10,000 \mathrm{gal} . \\ \text { Heating load } & 436.0 \times 10^{6} \mathrm{Btu} \\ \text { Cooling load } & 176.3 \times 10^{6} \mathrm{Btu} \\ \text { Hot water load } & 144.3 \times 10^{6} \mathrm{Btu} \\ \text { Cooling capacity } & 300,000 \mathrm{Btu} / \mathrm{Hr} \\ \% \text { Heating } & 67.4 \\ \% \text { Cooling } & 59.6 \\ \% \text { Hot Water } & 81.9\end{array}$




\section{COLLECTOR}

\section{Collector Field Selection}

Initial analysis of the solar heating system at the William O'Brien site was done for a 28-module collector network. A $14 \times 2$ collector array was c onsidered. However, even after incorporating energy. conserving improvements within the residence, a sufficient solar contribution was not attainable with the 504 square feet of collector area. Further analysis was done with a 36-module (648 sq. ft.) and a 33-module (594 sq. ft.) collector network. A 33-module collector field. was selected for the solar heating site although the performance gain with the 648-sq. - ft. collector array. was sizable. Special restrictions, esthetic appearance of the collector field structure, and the cost increase to incorporate a larger collector network were deciding factors in the final selection.

\section{Collector Array Design}

The collector field consists of two arrays joined to the internal residential plumbing by common supply and return lines. One is a $9 \times 2$ array ( 9 modules long and 2 module stacks high) and the other is a $5 \times 3$ array ( 5 modules long and 3 module stacks high). This arrangement satisfied special considerations, architectural design for integration with the residential structure, and esthetic appearance. The collector field is shown schematically in Figure 4-3. 


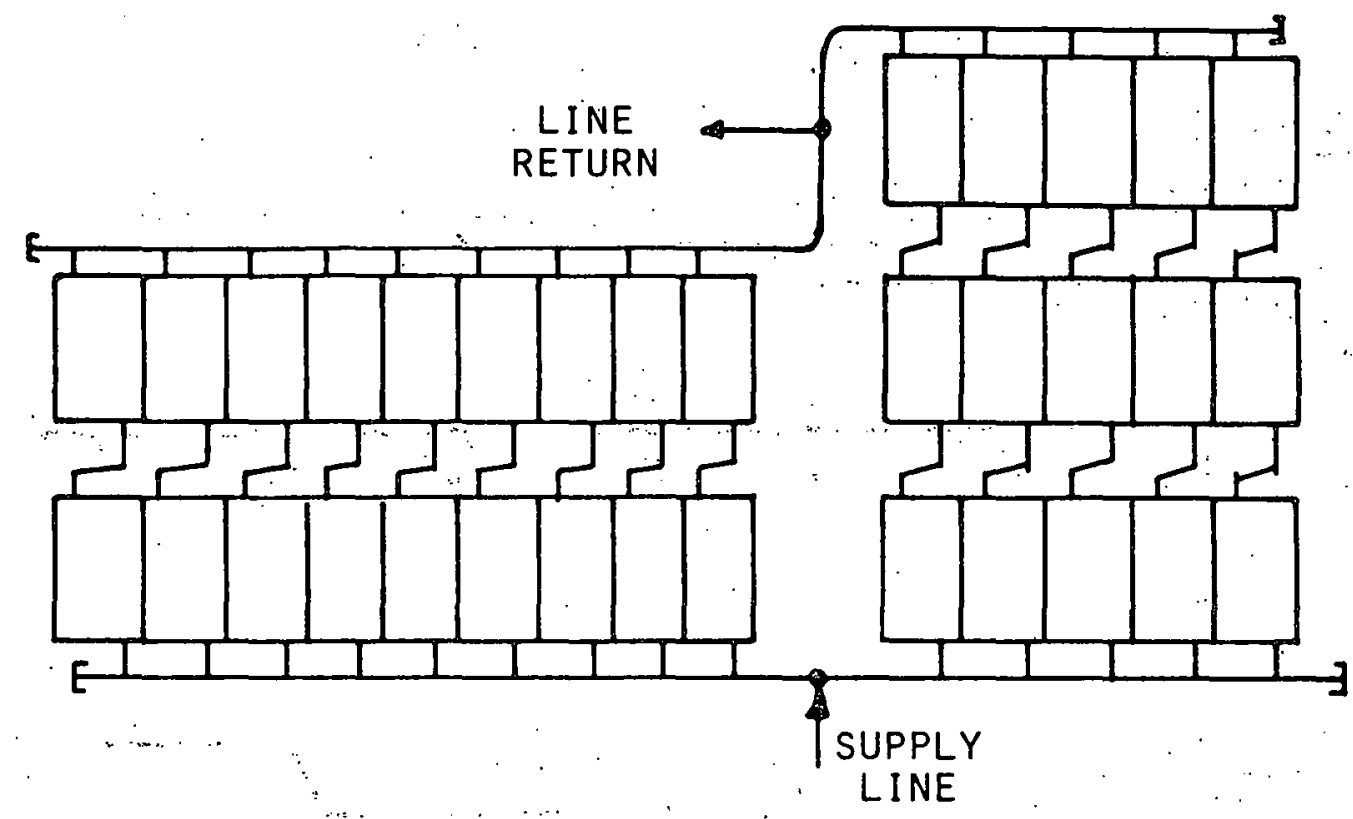

FIGURE 4-3. Schmetic of Collector Field

Figures 4-4 through 4-8 show design criteria used for determining collector array header sizes and flow arrangement, expected maximum flow variation and expected pressure drop. Figures $4-4$ and 4-5 summarize results obtained from computer simulation of various collector array configurations. The nominal flow for the William O'Brien site is $.86 \mathrm{gpm}$ through each collector module (12 gpm total flow). Extrapolating on the results presented by Figures 4-4 and 4-5, .7 gpm and .3. gpm through each collector module respectively, the following header sizes were selected:

- Nominal 1-inch headers for $9 \times 2$ array

- Nominal 3/4-inch headers for $5 \times 3$ array ....

The flow arrangement for both arrays is of direct return form (C-flow). Here, a pipe saving was obtained since the reverse return $(Z)$ arrangement would require the same size headers. Figures $4-6$ and $4-7$ show the expected extreme minimum flows, with respect to nominal, in the respective collector arrays: For the $9 \times 2$ array with nominal 1-inch headers, no collector module 
HEADER MATERIÁ́

FLUID

NOM. FLOW PER COLLECTOR

FLOW DEVIATION CRITERIA
COPPER (M)

$50 \%$ GLYCOL

.7 GPM

$15 \%$

$4-14$

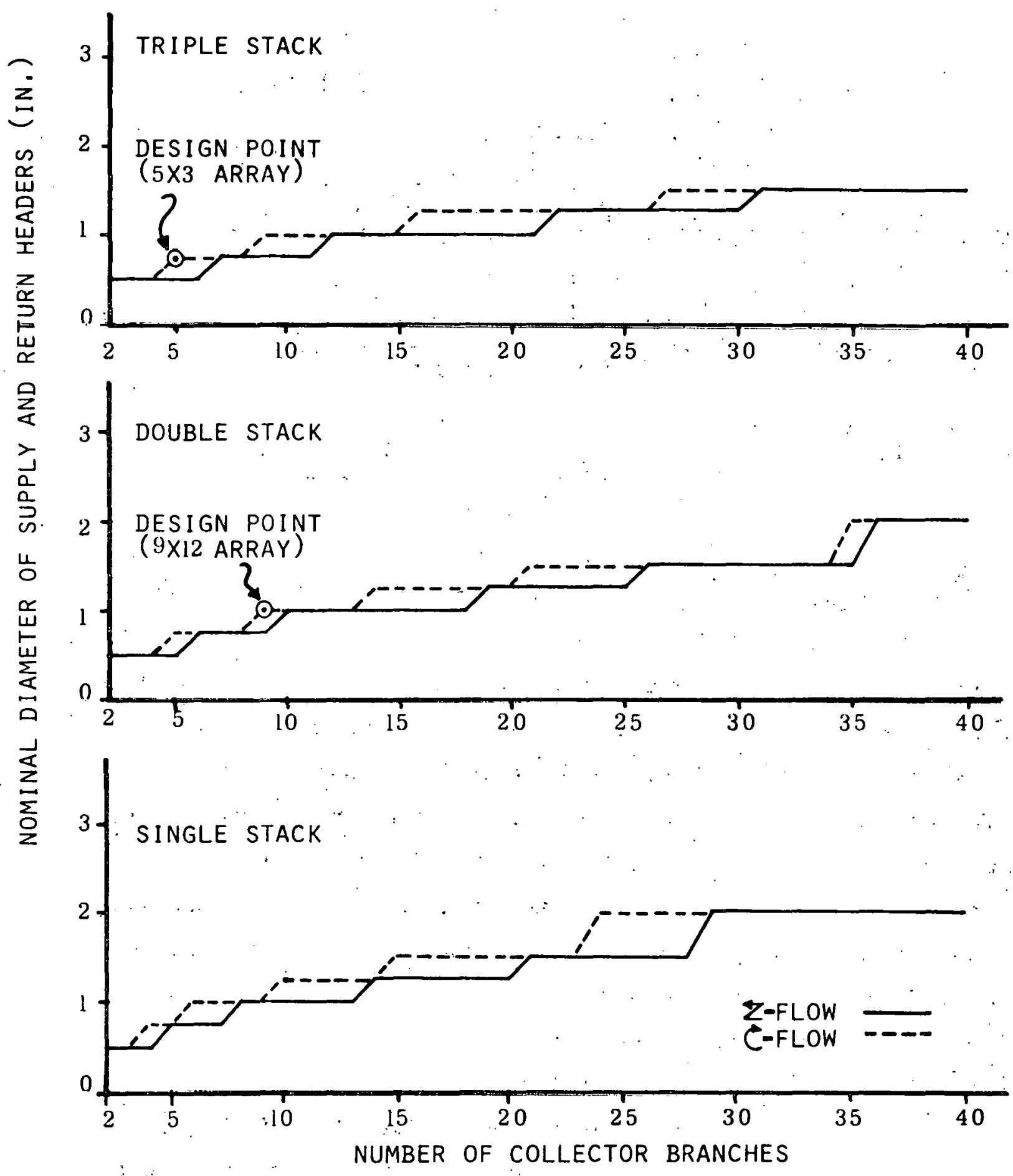

FIGURE 4-4. Minimum Header. Size for Series-Parallel Collectors A rray 
HEADER MATERIAL

FLUID

NOM. FLOW PER COLLECTOR

FLOW DEVIATION CRITERIA
COPPER. (M)

$50 \%$ GLYCOL

. 3 GPM

$15 \%$

. $4-15$

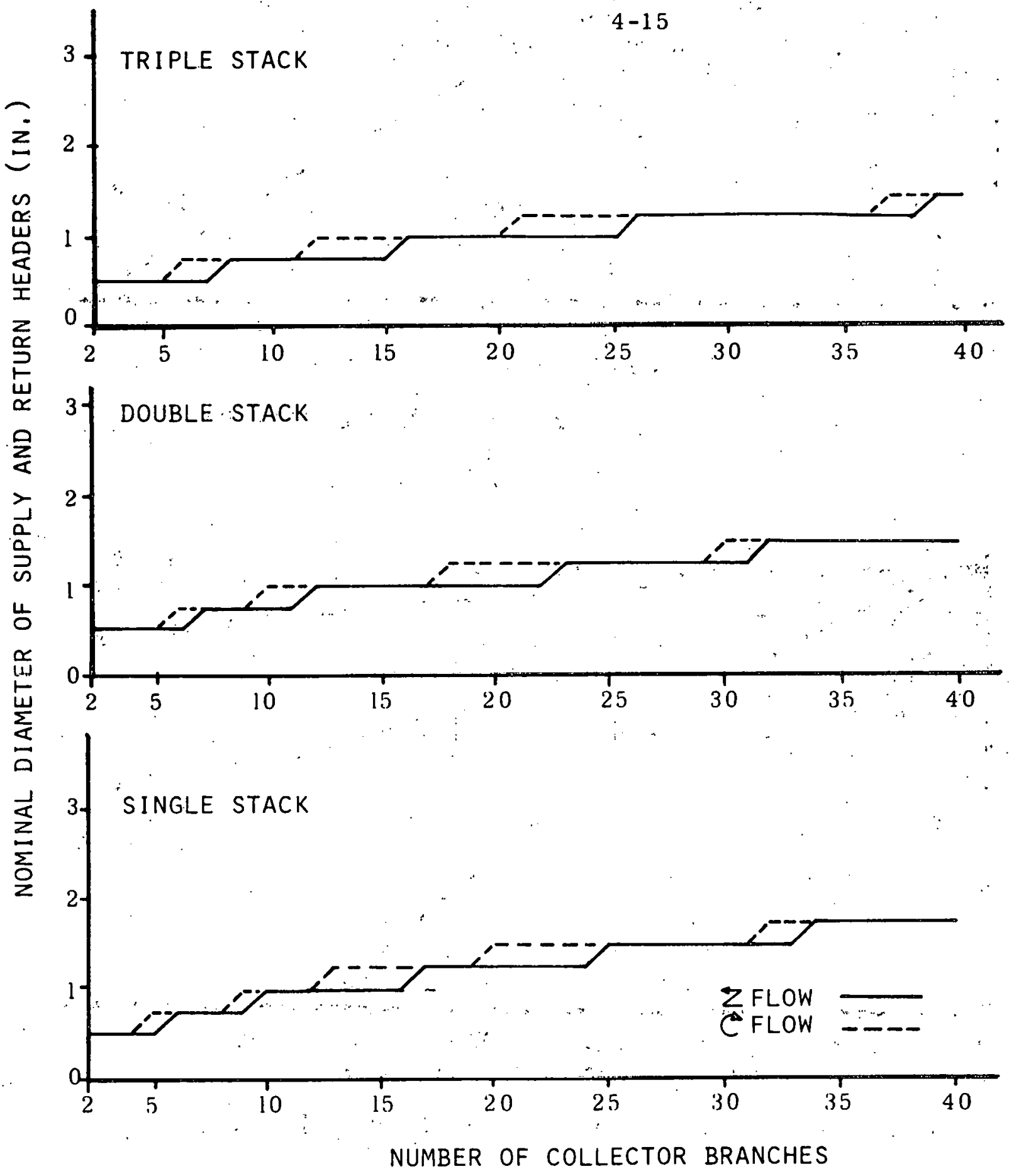

FIGURE 4-5. Minimum Header Size for Series-Parallel Collector Array 


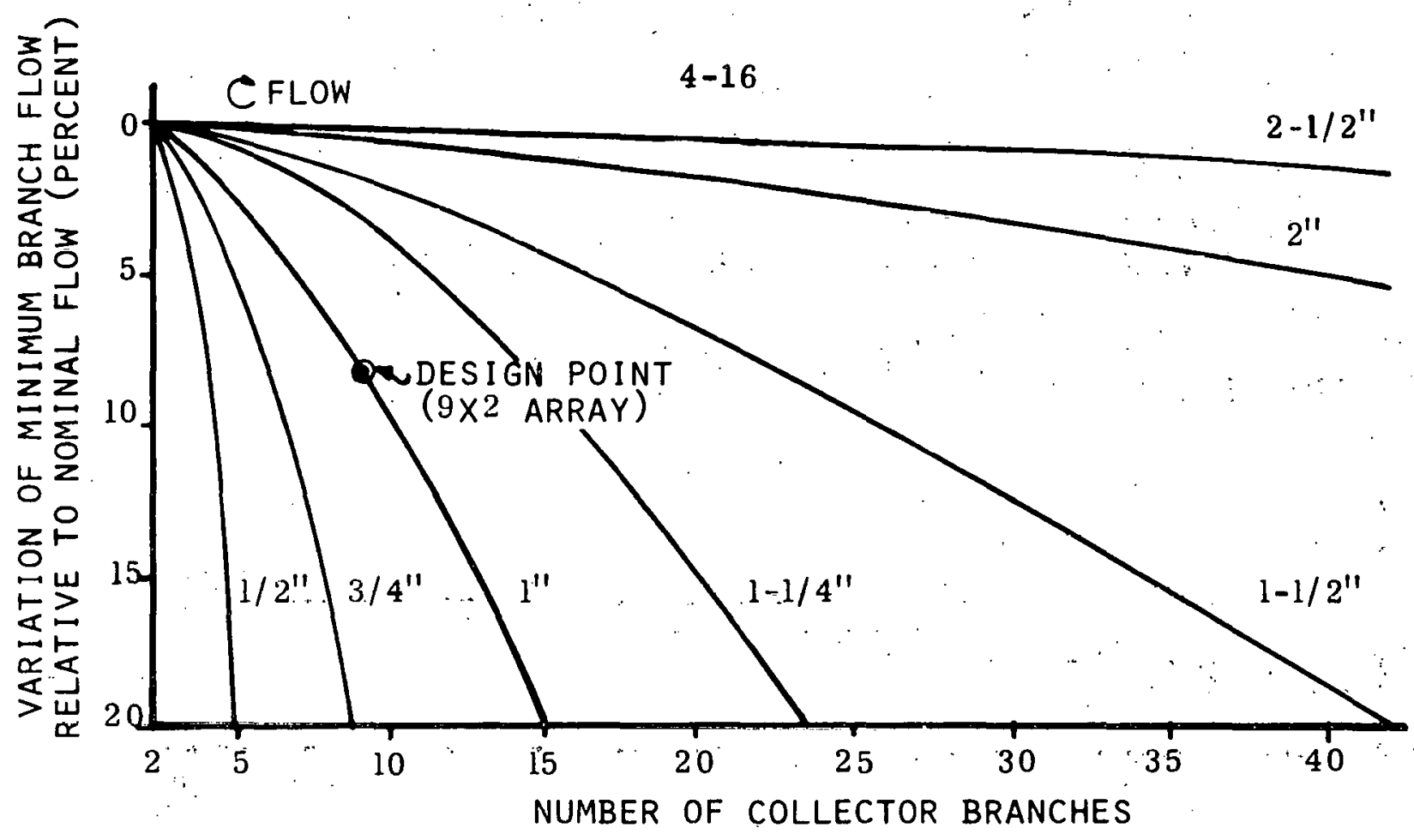

FIGURE 4-6. Flow Vairation for Series-Parallel Collector Array

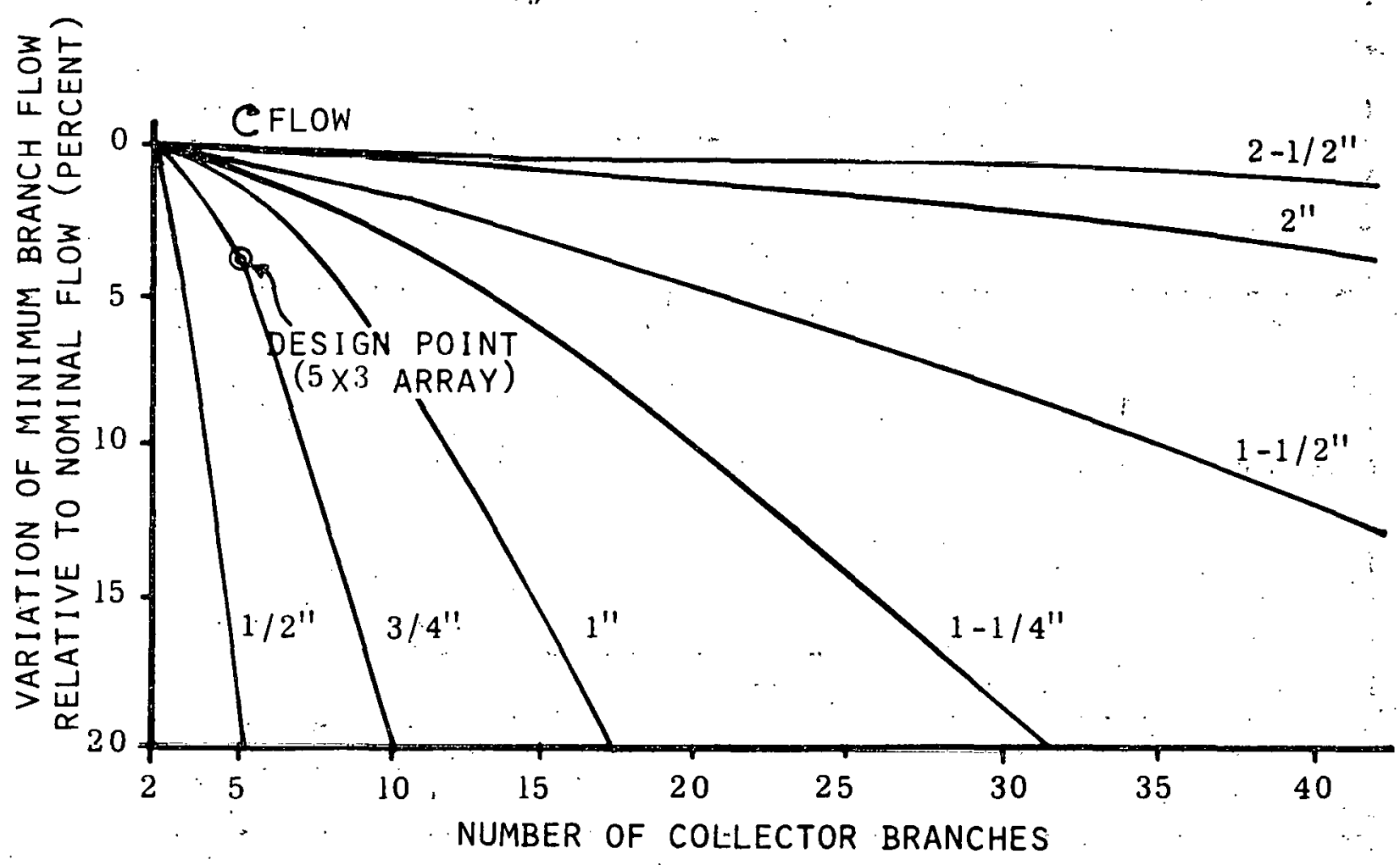

FIGURE 4-7. Flow Variation for Series-Parallel Collector A rray 
is expected to have a flow $8.5 \%$ less than nominal flow for that array. Similarly, for the $5 \times 3$ array with nominal 3/4-inch headers, no collector flow is expected to be less than $4 \%$ of nominal module flow for that array. Figure 4-8 shows expected pressure drops across collectors stacked one, two, and three high between two supply and return headers. Elevation change has not been taken into account since in a collector field the gravity head is returned to the system in the return line. For a $\mathrm{C}$-flow arrangement, the array pressure drop is the same as that across the first collector branch (i. e., first modules stacked between supply and return headers), and this b ranch has the most flow passing though it. The results presented in Figure 4-8 are applicable to predicting the pressure drop across a series parallel C-flow type of collector network using Lennox LSC-18 collectors. Figure 4-8 can also be used to estimate the pressure drop across a Z-flow type of collector network. A constriction for both cases is that the flow variation is not excessive between header branch lines. This requirement is usually met if the array is designed such that the pressure drop between supply and return headers is 3 to 4 times that along the supply header.

\section{Collector Field Summary}

Table 4-8 shows a tabulation of the prescribed collector network for the William $O^{\prime}$ Brien solar heating site and some expected results.

TABLE 4-8. Collector Network for Wm. O'Brien Site

\begin{tabular}{|c|c|c|c|c|c|}
\hline $\begin{array}{l}\text { Array } \\
\text { Config. }\end{array}$ & $\begin{array}{c}\text { Flow } \\
\text { Arrangement }\end{array}$ & $\begin{array}{l}\text { Header } \\
\text {-Type } \\
\end{array}$ & $\begin{array}{l}\text { Nom } \\
\text { Size } \\
\end{array}$ & $\begin{array}{l}\text { Nom } \\
\text { Flow } \\
\end{array}$ & $\begin{array}{l}\text { Expected Flow } \\
\text { Variation W. R.T. } \\
\text { Nominal }\end{array}$ \\
\hline $9 \times 2$ & $C-$ flow & Copper (M) & 1 in. & $.86 \mathrm{gpm}$ & $-9 \%$ to $+22 \%$ \\
\hline $5 \times 3$ & $C-$ flow & Copper (M) & $3 / 4$ in. & $.86 \mathrm{gpm}$ & $-4 \%$ to $+8 \%$ \\
\hline
\end{tabular}




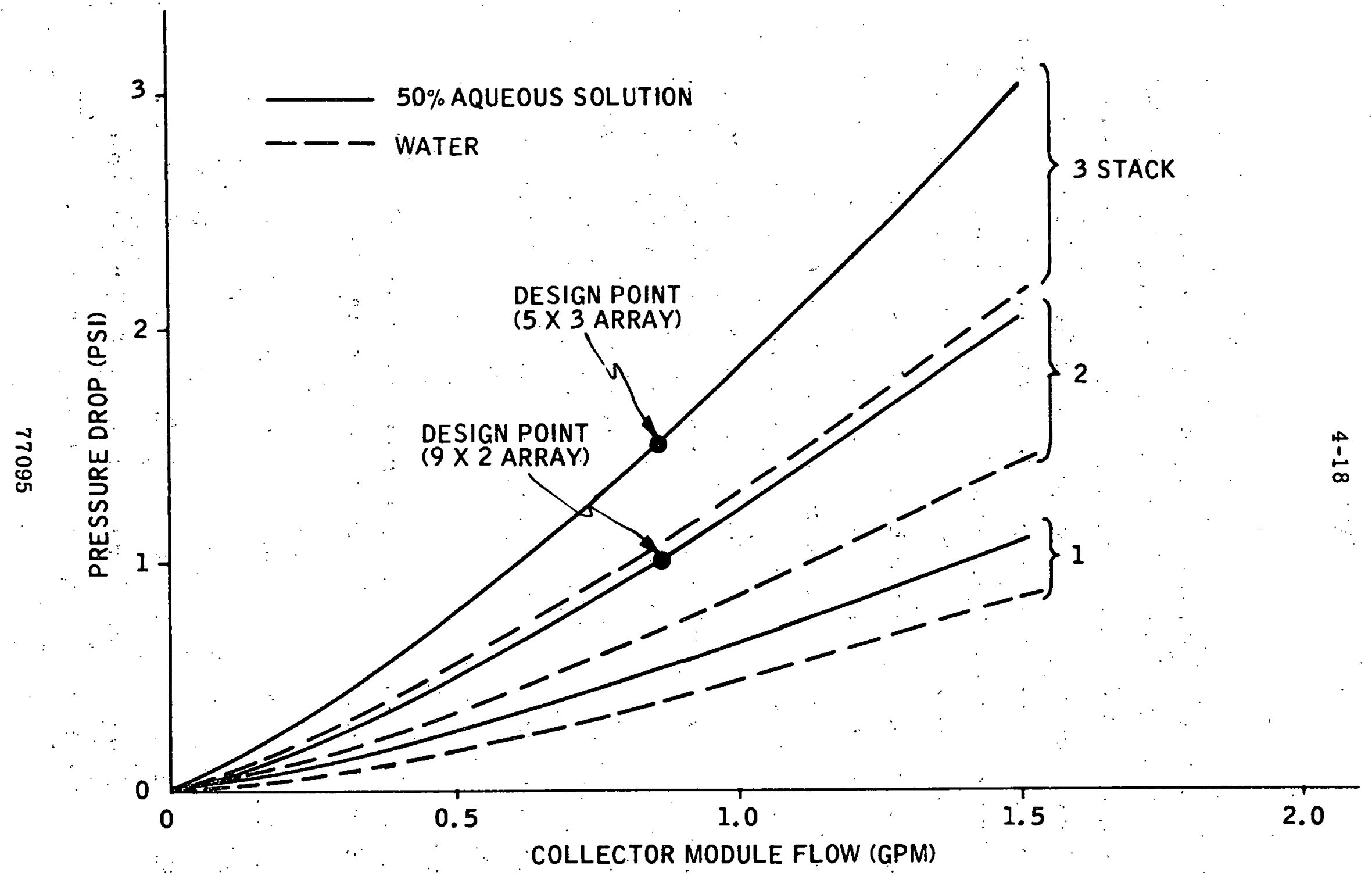

FIGURE 4-8. Pressure Drop Across Stacked Collectors in Series 


\section{Collector Qualification Tests}

Final performance tests of collectors exposed in Phoenix, Arizona, are now in progress. Test results are expected by July 27; the final report will be issued two weeks after that date.

SPACE HEATING AND AUXILIARY HEATING

\section{Work Accomplished}

During the past quarter, the developmental work on the subsystems for which Lennox is responsible has maintained a vigorous pace. Most of the work required on the space heating and auxiliary energy subsystems has been completed. Much of the remaining work involves finalizing drafting layouts, building prototype hardware, completing performance tests on the subsystems (except 25-ton cooling, which has not been completely assembled), developing I. O. M. manuals and completing other tasks to produce a total subsystem package.

Another situation that developed this quarter was the request to substitute a heat pump and electric heat for one of the single-family heat only auxiliary energy subsystems. The developmental work for this change has been completed; however, technical details were not available for this report and will be included in the next monthly report. 
Residential Subsystems --

Coil Performance -- The residential solar coil was tested; experimental results are summarized in the Monthly Report of May, 1977.

All Performance calculations were initially done for water and 50\% ethylene glycol solution. Since $25 \%$ ethylene glycol is going to be used in the field installation, a few correction factors have been determined.

Drop test on the coil carton and other preshipment tests already conducted indicate that the coil will not be damaged during the shipping process.

Commercial Subsystems --

Commercial Unit GCS3-1853-500 - Modifications -- The original commercial unit was modified to have heat only components and to accommodate a solar coil. All the cooling components such as two compressors, an evaporator coil, two outdoor fans and a condenser coil were removed. The modified unit basically consists of two blowers, an auxiliary energy heat exchanger and a solar coil. The overall size of the modified unit is the same as the original unit.

Modified GCS3-1853-500 - Wiring and Controls -- The unit received from the Stuttgart (Arkansas) Plant of Lennox Industries Inc. had all the controls of the original unit as shown in Figure 4-9. The wiring of the unit was modified as shown in Figure 4-10 to suit solar applications. The commercial unit will operate in three modes, i. e., Heat 1 , Heat 2 and cool. In the cooling mode, cooling will be provided only by outside air provided the outside air has lower enthalpy. 


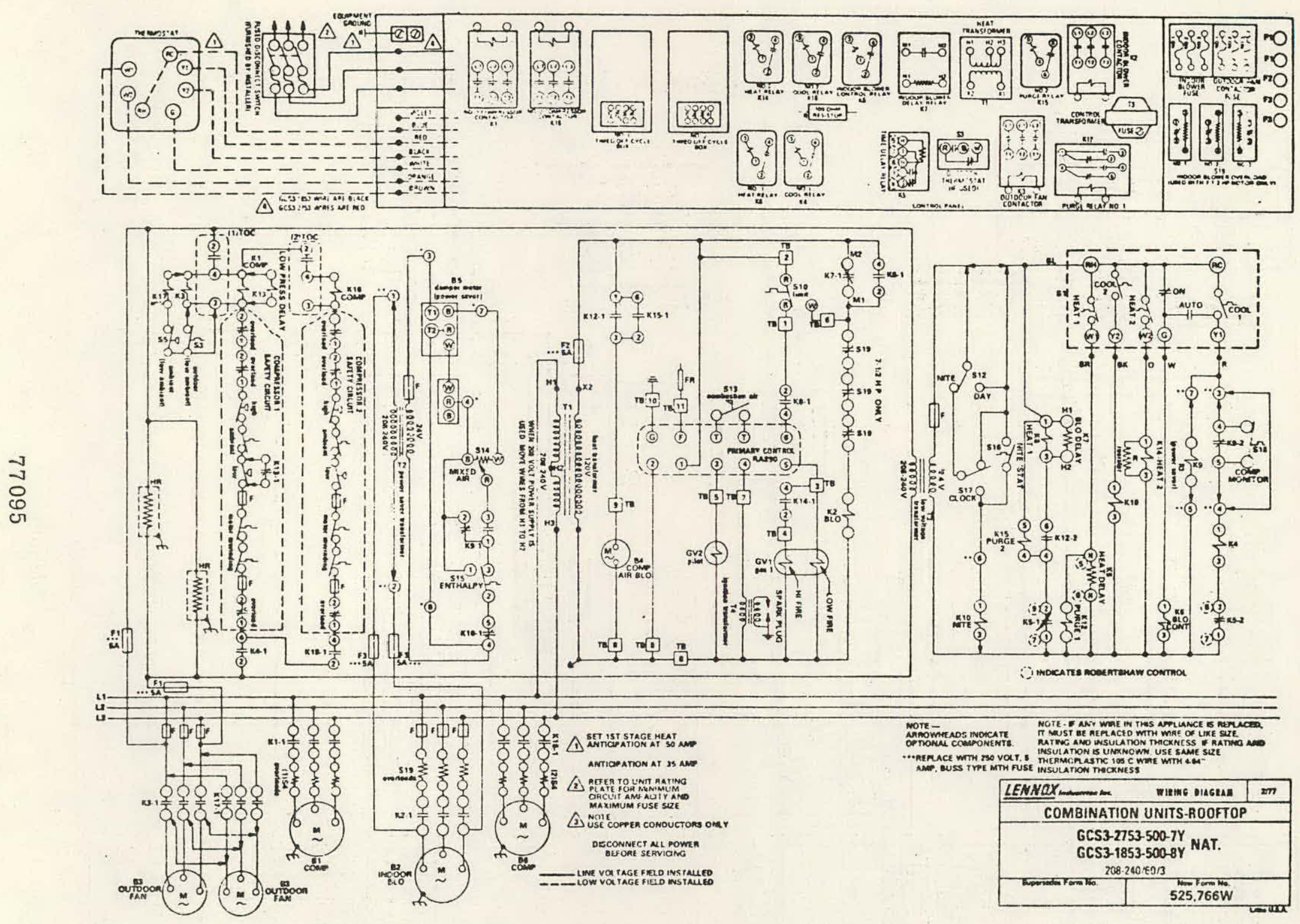

$\stackrel{\stackrel{P}{1}}{\stackrel{1}{上}}$

FIGURE 4-9. Lennox Unit Showing Controls 


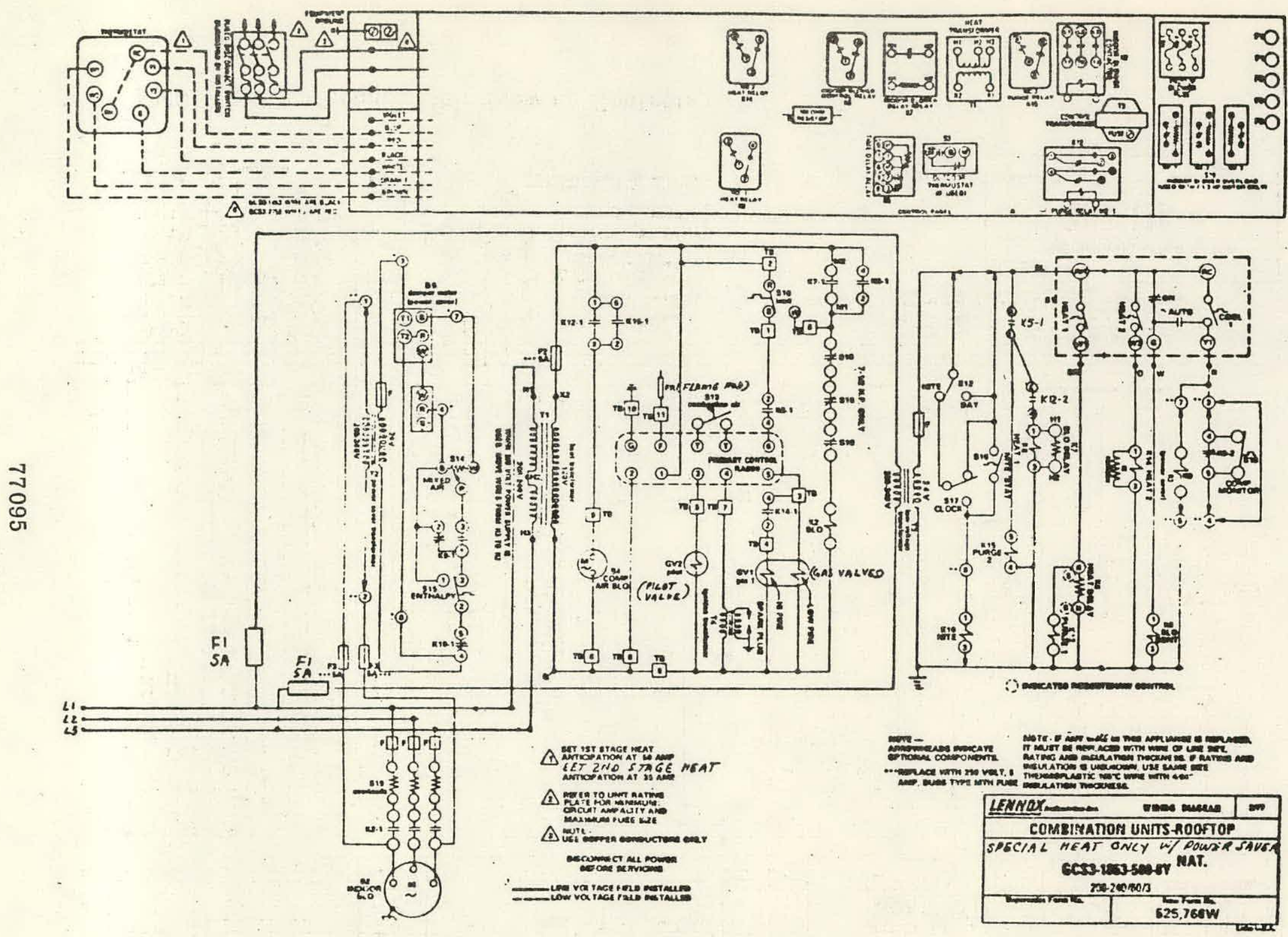

- FIGURE 4-10. Modified Wiring in Lennox Unit 
Vibration Test -- A new motor/blower mounting frame was designed so the solar coil could be placed upstream of the blowers. It consists of support and bearing frames shown in Figure 4-11 and 4-12. The bearing frame is bolted to the support frame through five vibro absorbers. The support frame is rigidly connected to the cover panel supports. Figures 4-13 and 4-14 show the side and top views of the blower compartment. The vibro absorbers reduce transmittance of the vibrations from the bearing frame to the support frame. The motor is bolted to the motor support shown in Figure 4-14. Bearing wheels are supported by the bearing frame through the blower. shaft, two bearings and two bearing supports. Torque from the motor to the blower wheels is transmitted by a belt and pulley arrangement. Figure 4-15 shows three views of the motor/blower mounting frame in the blowe $r$ compartment.

To check whether the new motor/blower mounting frame met Lennox vibration standards, vibration tests were conducted on the frame with the setup shown in Figures 4-16 and 4-17. The blower was run at 970 R.P.M. An accelerometer was placed at six locations, as shown in Figure 4-18, and one by one, the vertical accelerations were plotted with an $\mathrm{x}-\mathrm{y}$ plotter for each of the locations. Figure 4-19 shows a sample accelerograph. The vibration data for two conditions, without any unbalance on the blower wheels and with an unbalance of $150 \mathrm{gms}$ on each whee 1 , showed that, with and without unbalance the maximum peak velocities were $0.768 \mathrm{in} . / \mathrm{sec}$, and $0.257 \mathrm{in} / \mathrm{sec}$, respectively. For both cases, the peak velocity was above the maximum

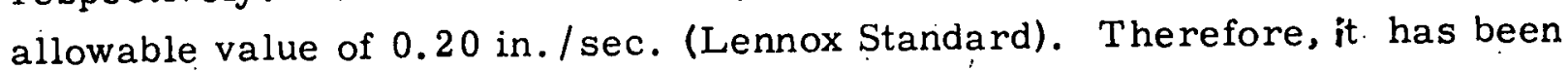
decided to modify the motor/blower mounting frame to reduce vibration, and the vibration tests will be conducted again. 


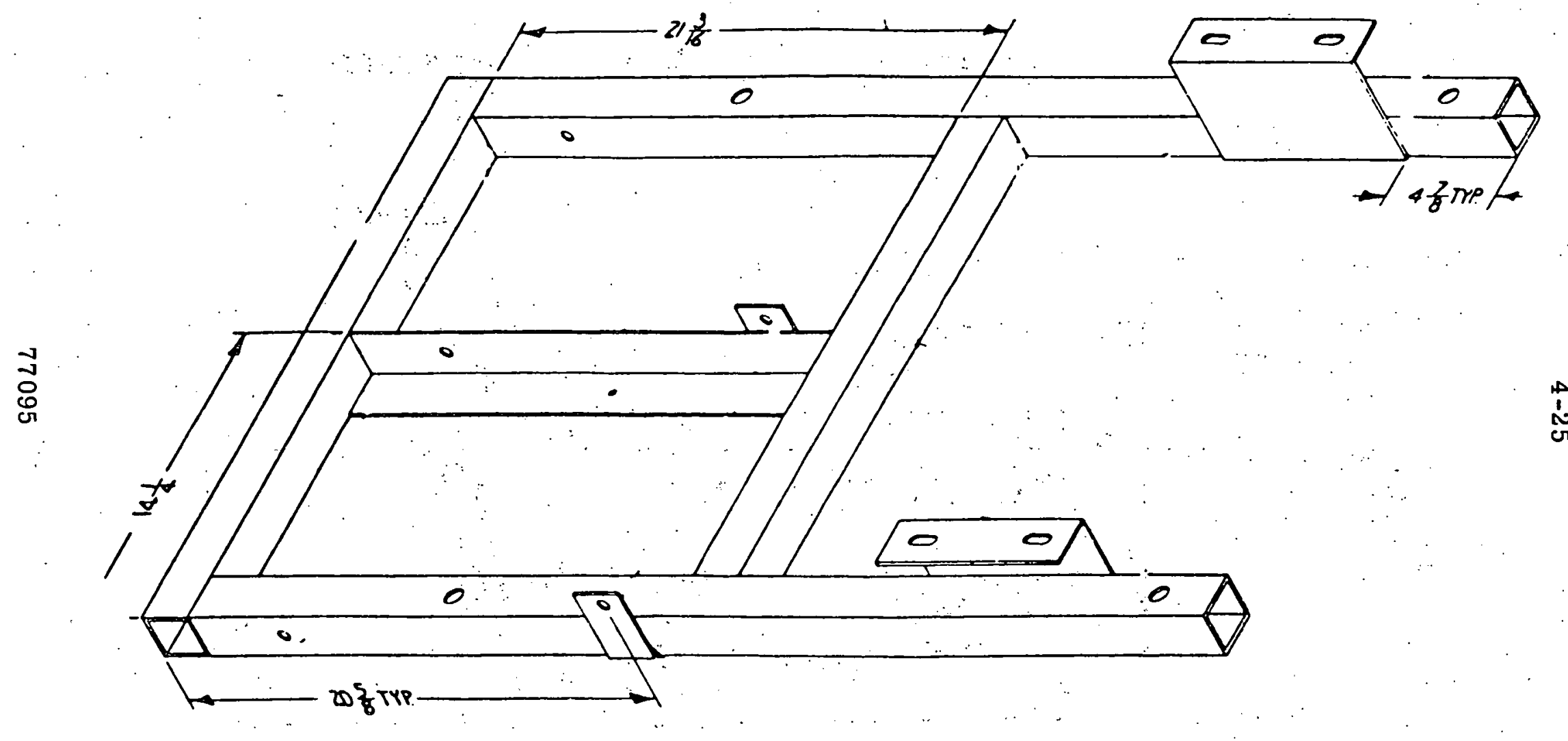

i

FIGURE 4-12. Bearing Frame 


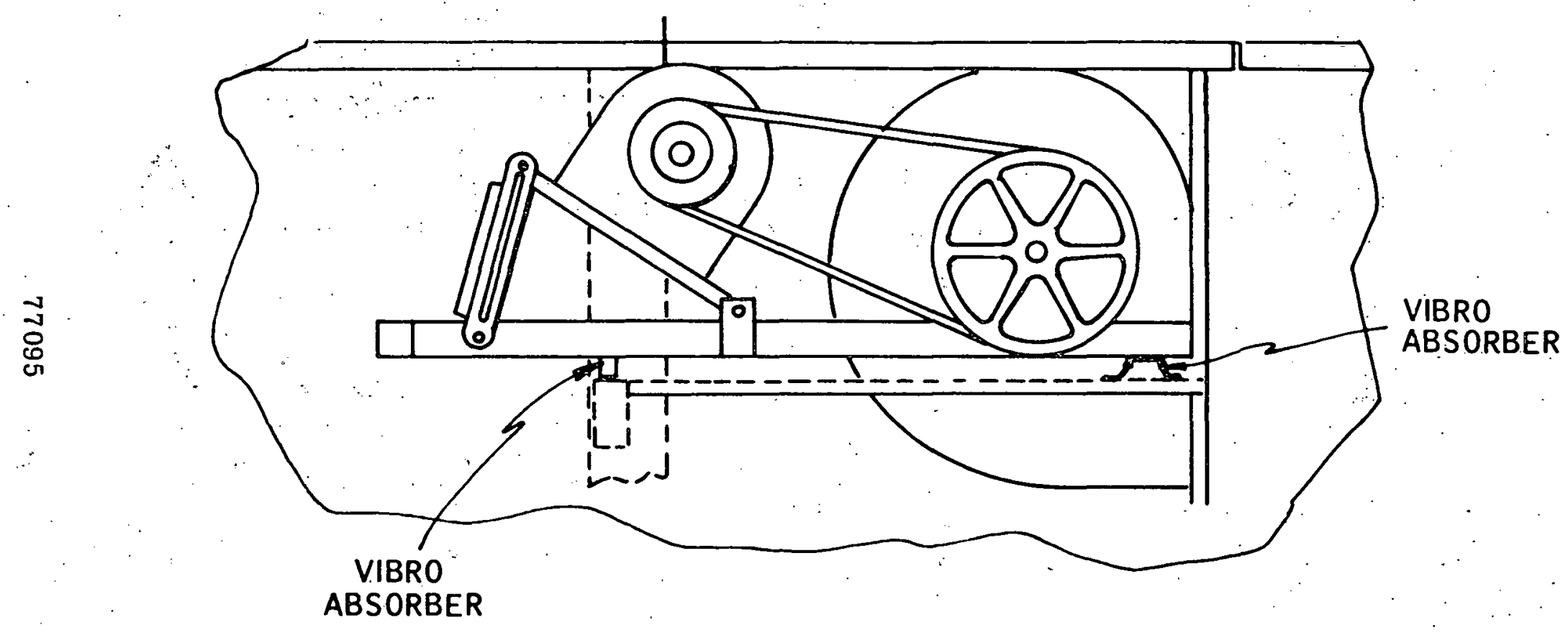

ث̀

FIGURE 4-13. Side View of Blower Compartment 


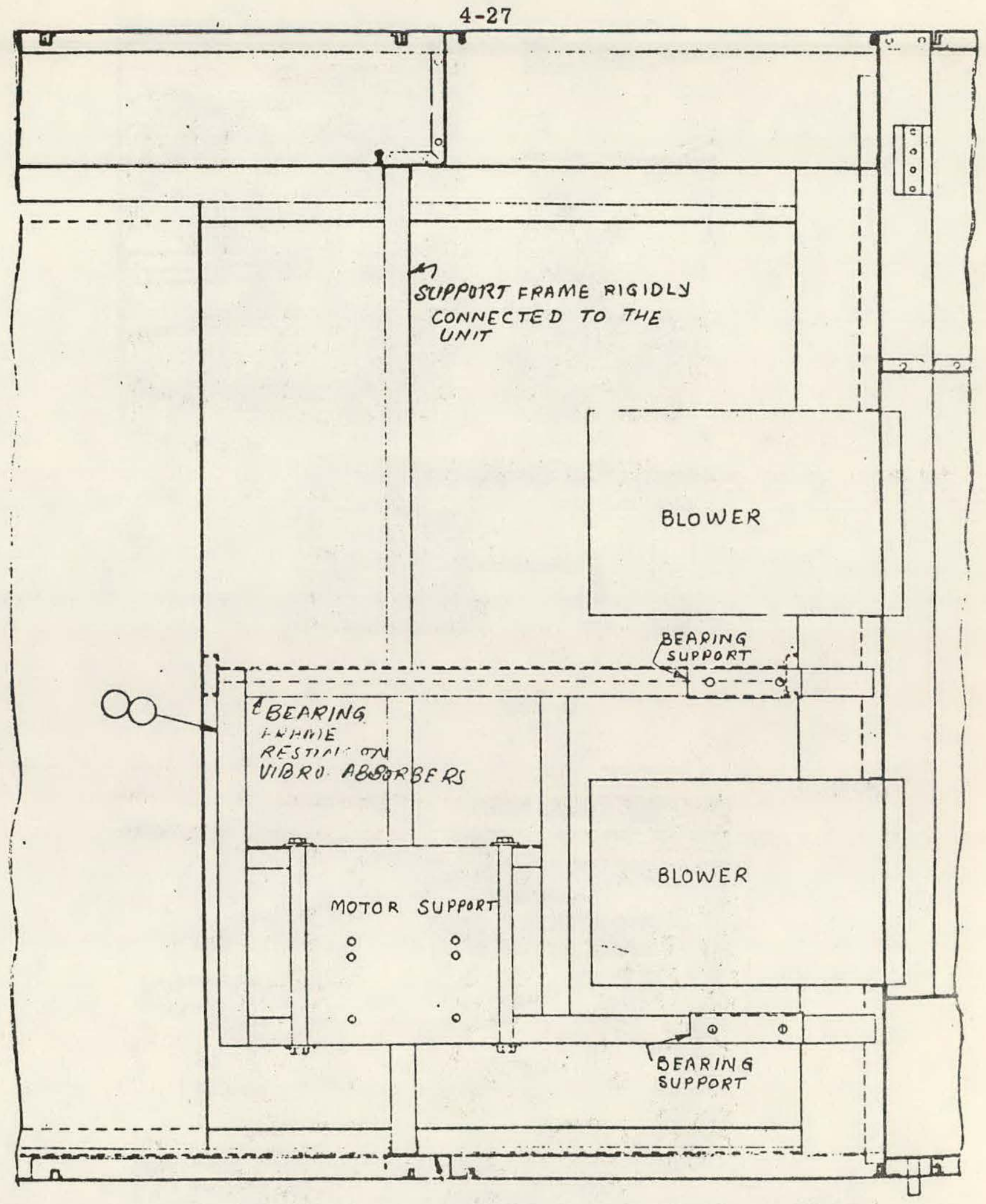

FIGURE 4-14. Top View of Blower Compartment 


\section{$4-28$}

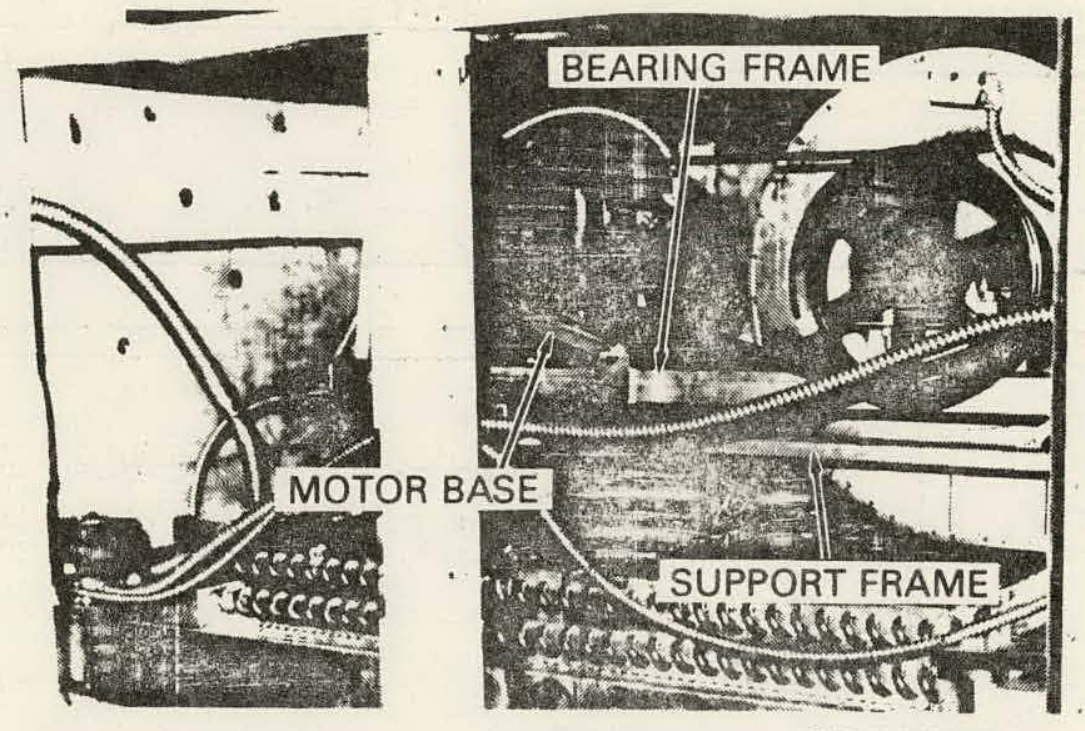

SIDE VIEW
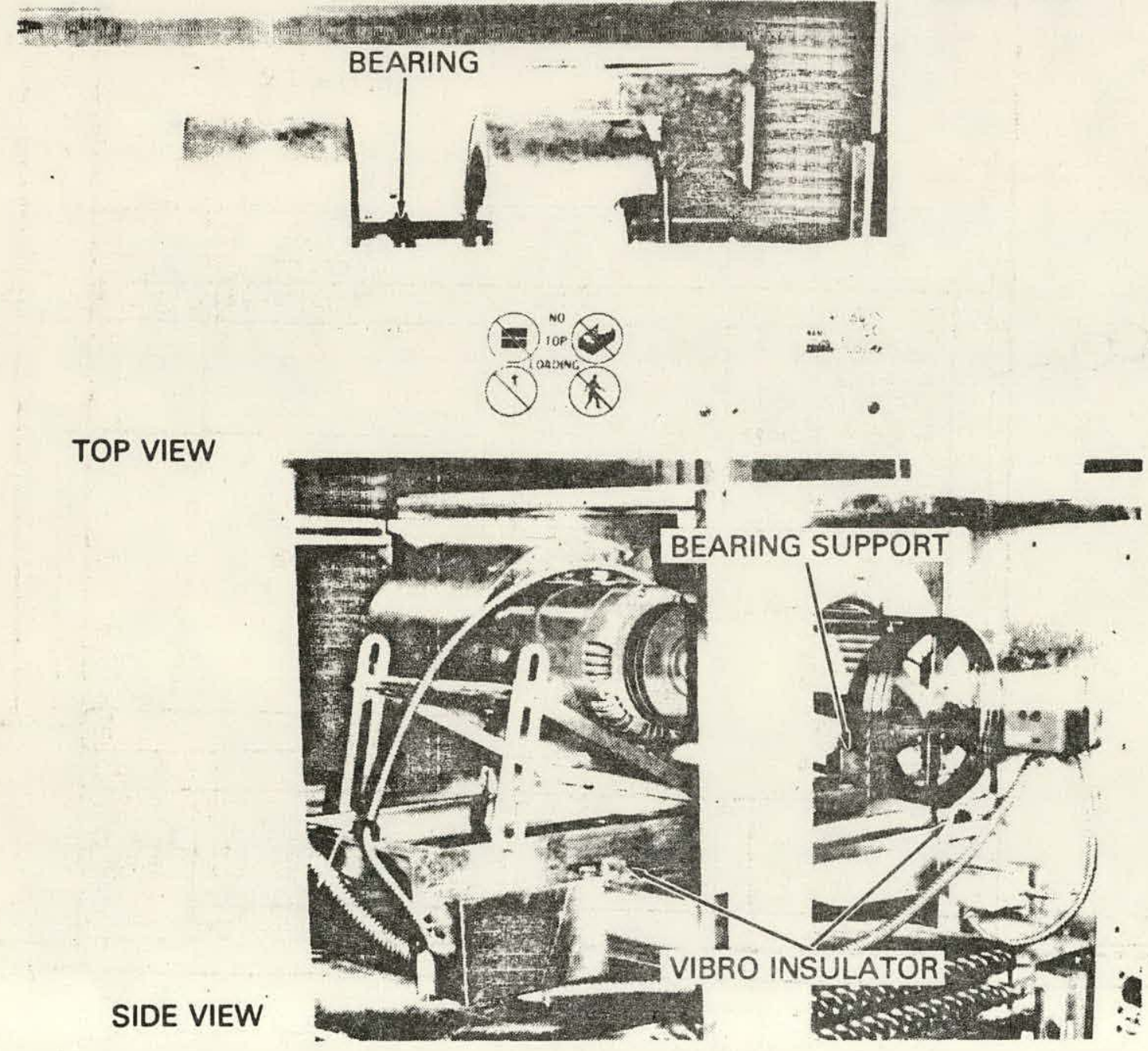

FIGURE 4-15. Blower Compartment 


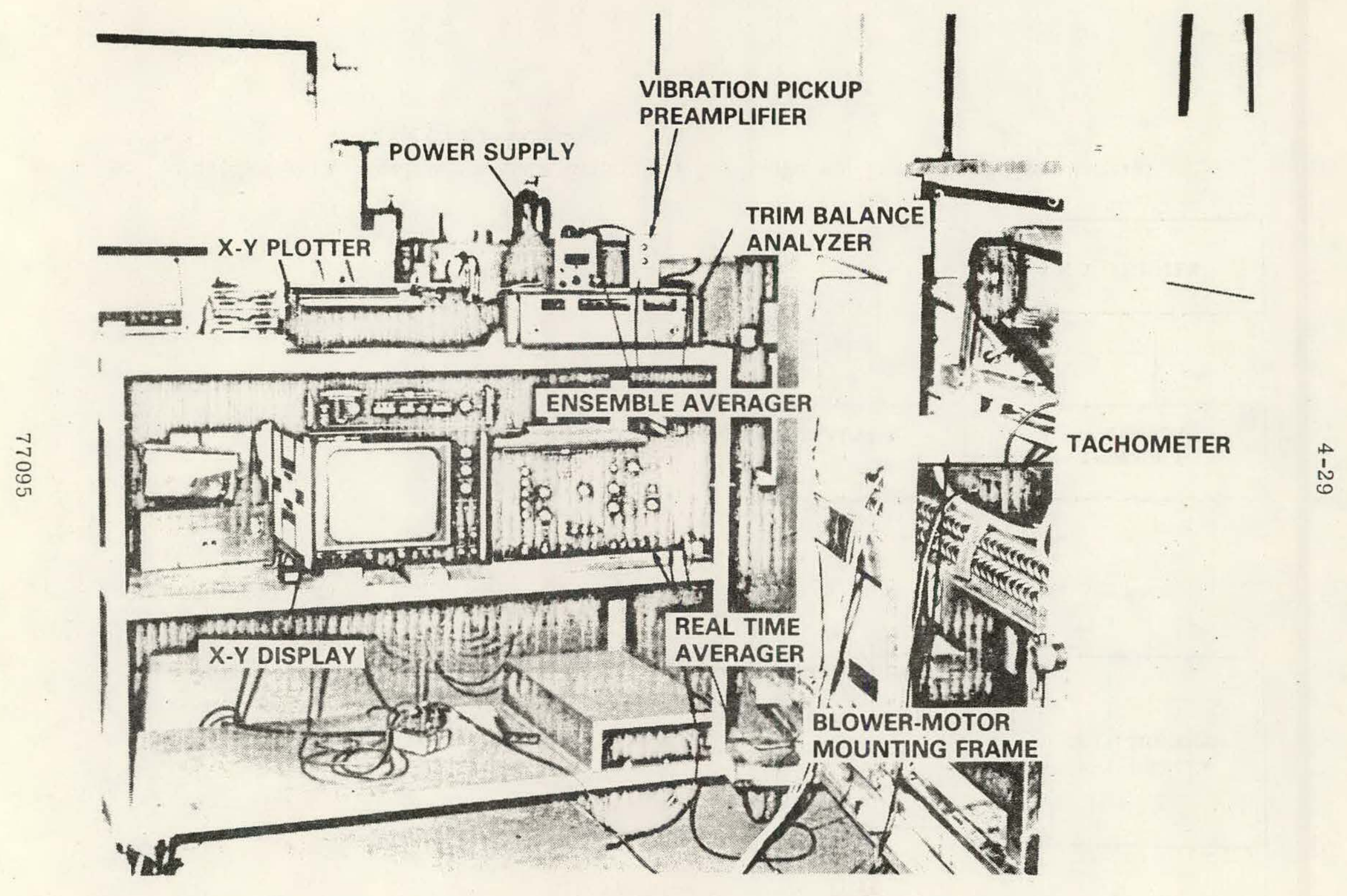

FIGURE 4-16. Vibration Test Setup 


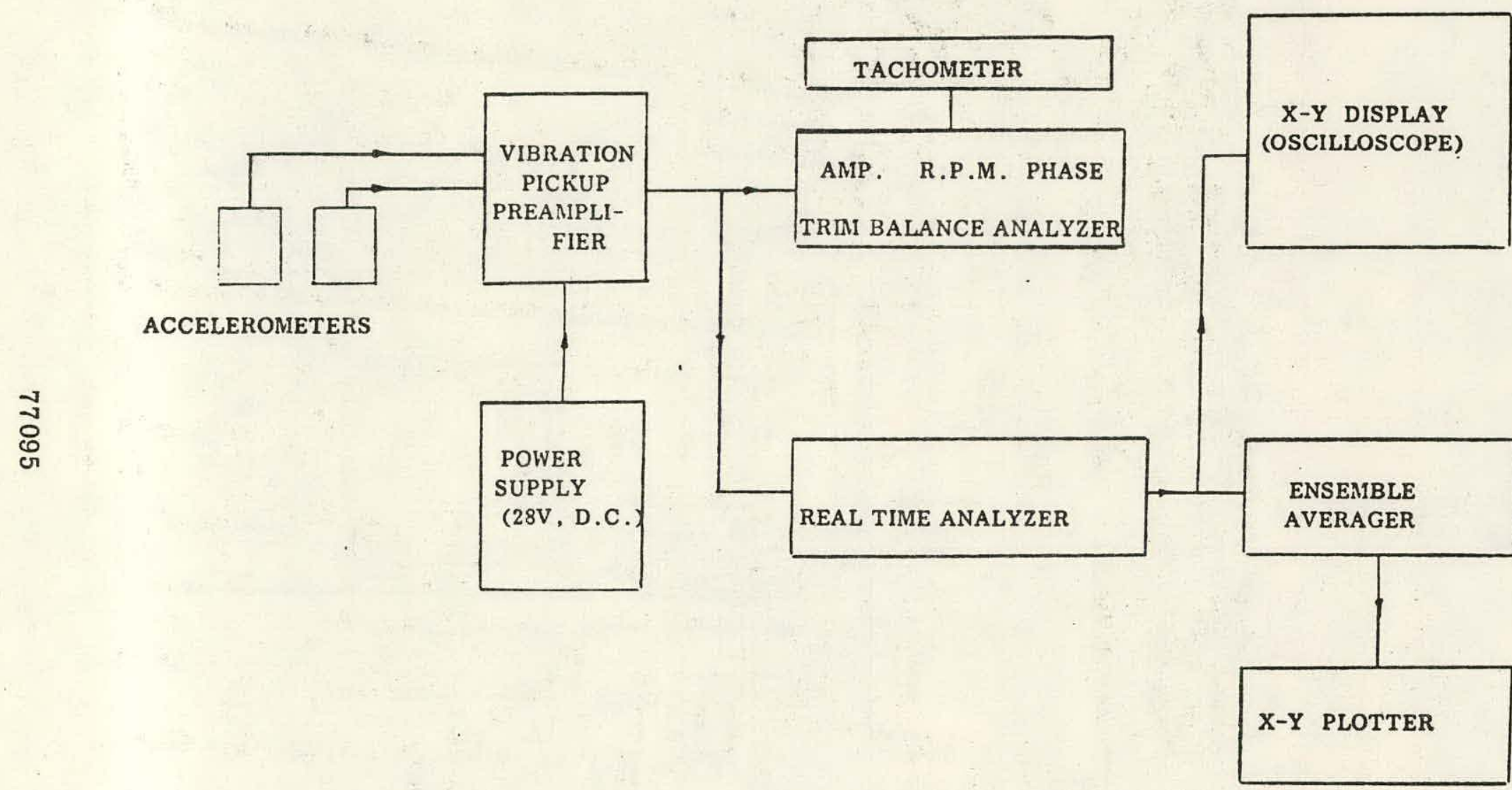

FIGURE 4-17. Instrumentation Schematic for Vibration Test on the Commercial Unit GCS3-1853-500 


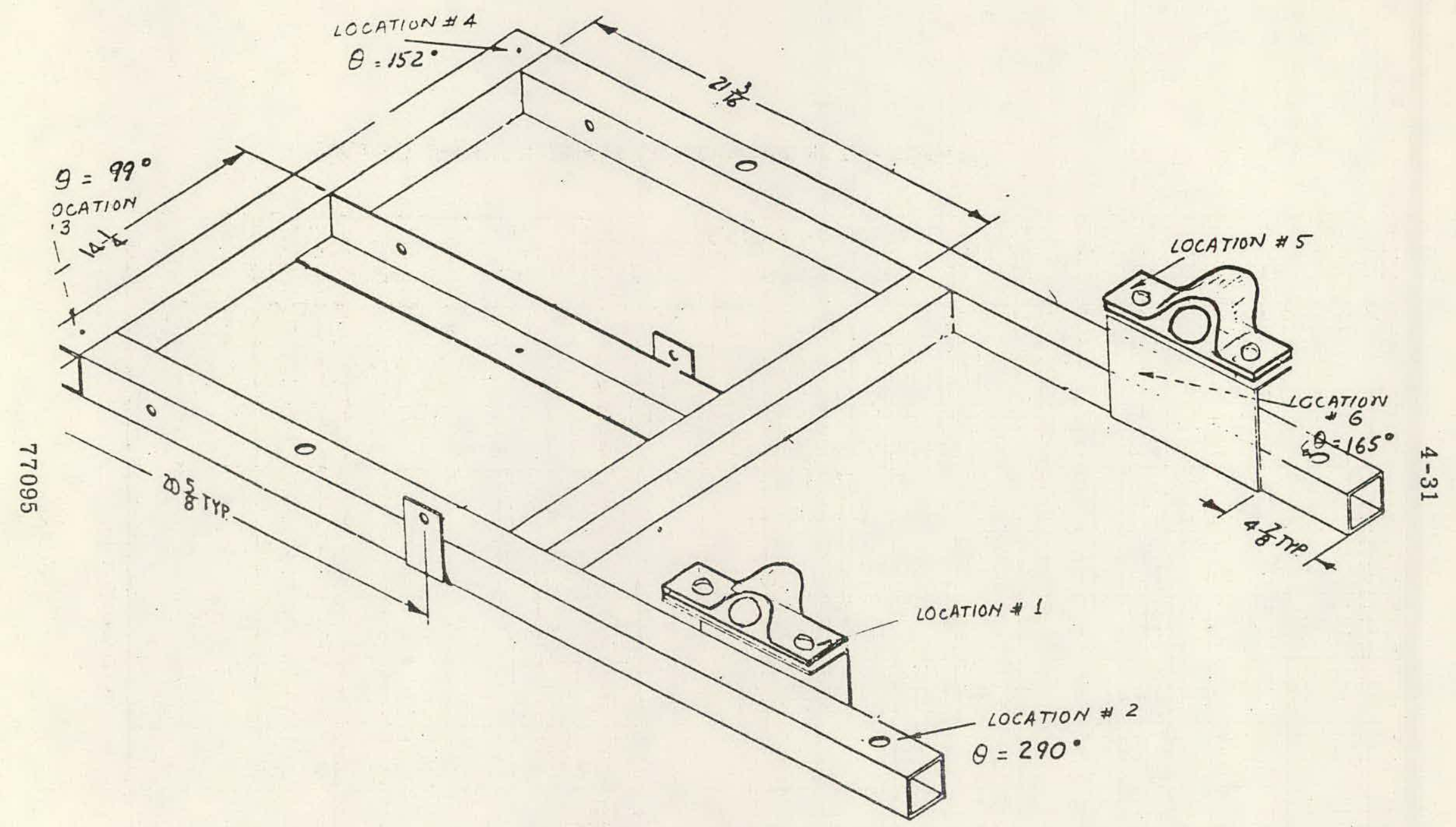

FIGURE 4-18. Accelerometer Locations 


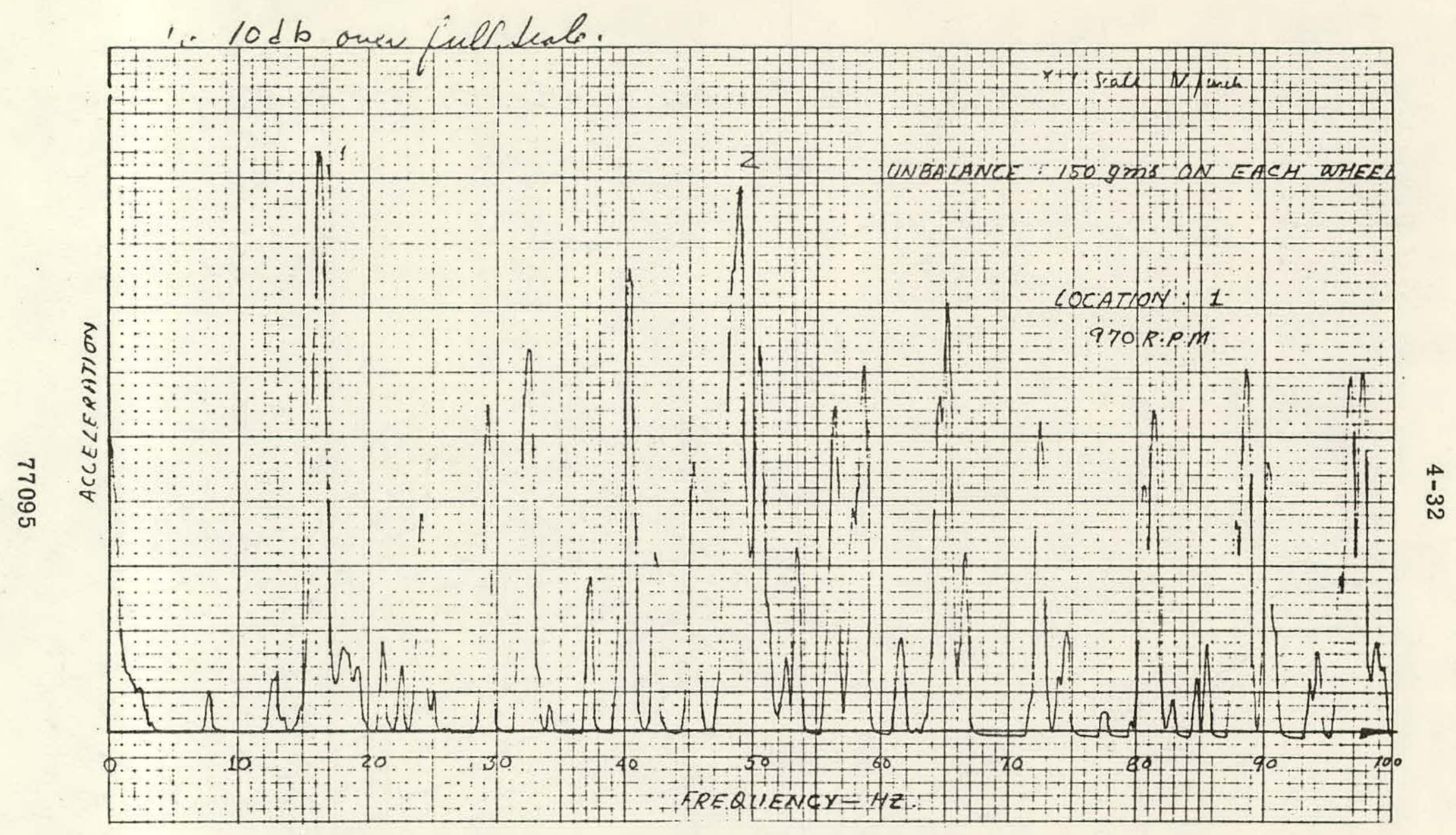

FIGURE 4-19. Vertical Acceleration at Location No. 1 
Combustion Tests - - The combustion tests were conducted in accordance with clause 2.4 of AGA Standard ANSI Z21-47-1973 for the following gas inputs:

- 418,482 Btu/hr. (Production Órifice, 31/64")

- $501.182 \mathrm{Btu} / \mathrm{Hr}$. (Oversize Orifice, $17 / 32^{\prime \prime}$ )

For both the tests, the concentration of $\mathrm{CO}_{2}$ and $\mathrm{CO}$ in the flue gases were in the ranges 2.3 to 7.7 percent and 0.0020 and 0.0240 percent respectively.

The modified unit meets AGA combustion standard because carbon monoxide concentration in the flue gases is less than 0.04 percent for all tests.

Thermal Efficiency - The thermal efficiency of the modified unit was. determined experimentally in accordance with A.G.A. Standard

ANSI Z21.47-1973. The purpose of thermal performance tests was twofold:

first to determine thermal efficiency and second to study the change in thermal efficiency due to increased return air temperature." Following are the test results:

Gas Input: $501,366 \mathrm{Btu} / \mathrm{hr}$.

Return Air $\quad \%$ Thermal
Temp. $-{ }_{\mathrm{F}} \quad \cdots$ The

$\begin{array}{rrr}88 & & 76.5 \\ 98 & & 76.4 \\ 121 & \ddots & 76.1 \\ 137 & & 75.9\end{array}$

The change in thermal efficiency of the modified unit due to increased. return air temperature $(88-137)$ is less than $1 \%$. Since this is not less than $75 \%$, the modified unit meets the thermal performance standard (A.G.A. Standard ANSI Z21.47-1973). 
Hot and Cold Spots Tests -- Forty-eight tests were conducted to determine hot and cold spots on the auxiliary energy heat exchanger. Four: baffles have been added to the heat exchanger section to remove the observed hot and cold spots. Further details of the tests will be reported in the next report because test data is being processed now.

Motor Temperature Tests - - Tests were conducted to determine the temperature of windings at different static pressures for high return air temperatures. Test results will be reported next month because the test data has not yet been processed.

Limit Control -- Tests on limit control have been completed, and data is being processed.

Blower Air Capacity -- Tests to determine air handling capacity of. . the blowers at different speeds and static pressures are in progress.

\section{Plans for Next Quarter}

- Modify the design of the residential solar coil to accommodate a drain pan and then to conduct a blowoff test on the coil.

- Finish processing the test data already collected for modified GCS3-1853-500.

- Conduct blower air handling tests on the modified commercial unit.

- Improve the design of the motor/blower mounting frame to reduce the vibration.

- Conduct further vibration tests on the improved motor/blower mounting frame.

- Attend Prototype Design Reviews for Heat Only Subsystems. 
ENERGY TRANSPORT SUBSYSTEM

During this quarter, work was accomplished on further refinement of the circulating pump, heat transfer fluid, and piping selection.

Excluding the piping between subsystems, the Energy Transport Module (ETM) discussed below includes transport subsystem components for SFRH applications.

\section{Objective}

To reduce installation time, associated cost, and physical space required to interconnect residentialsolar hydronic subsystems, a majority of the Energy Transport Subsystem components have been modularized into a factory-built cabinet. The resulting ETM, when incorporated properly into a solar heating system, will provide a consistent, flexible interface between subsystems in various residential applications.

\section{Design Goals}

The ETM was designed to achieve the best matrix and arrangement of components within a functional, compact cabinet: Of the system components, 30 percent are included within the ETM (see Table 4-9 and Figures 4-20 and 4-21). Tradeoffs have been made between component installation costs of onsite work against shop installation costs for the modules. The constraints analyzed included, but were not limited to, the following: 


\section{General}

1) Accommodation of the constraints listed below will not adversely affect the function or efficiency of the Energy Transport Subsystem.

2) The ETM must interface with various-sized residential solar heating systems.

3) Requirements of the Residential Interim Performance Criteria (Jan. 1, 1973) must be met.

TABLE 4-9. Shop Installed Components

Amount

3
1
1
1
2
1
1
3
3
1
1
1
1
3

Component

Total $=23 \quad$ Components within ETM (plus piping, fitting, ' wiring, and insulation) 


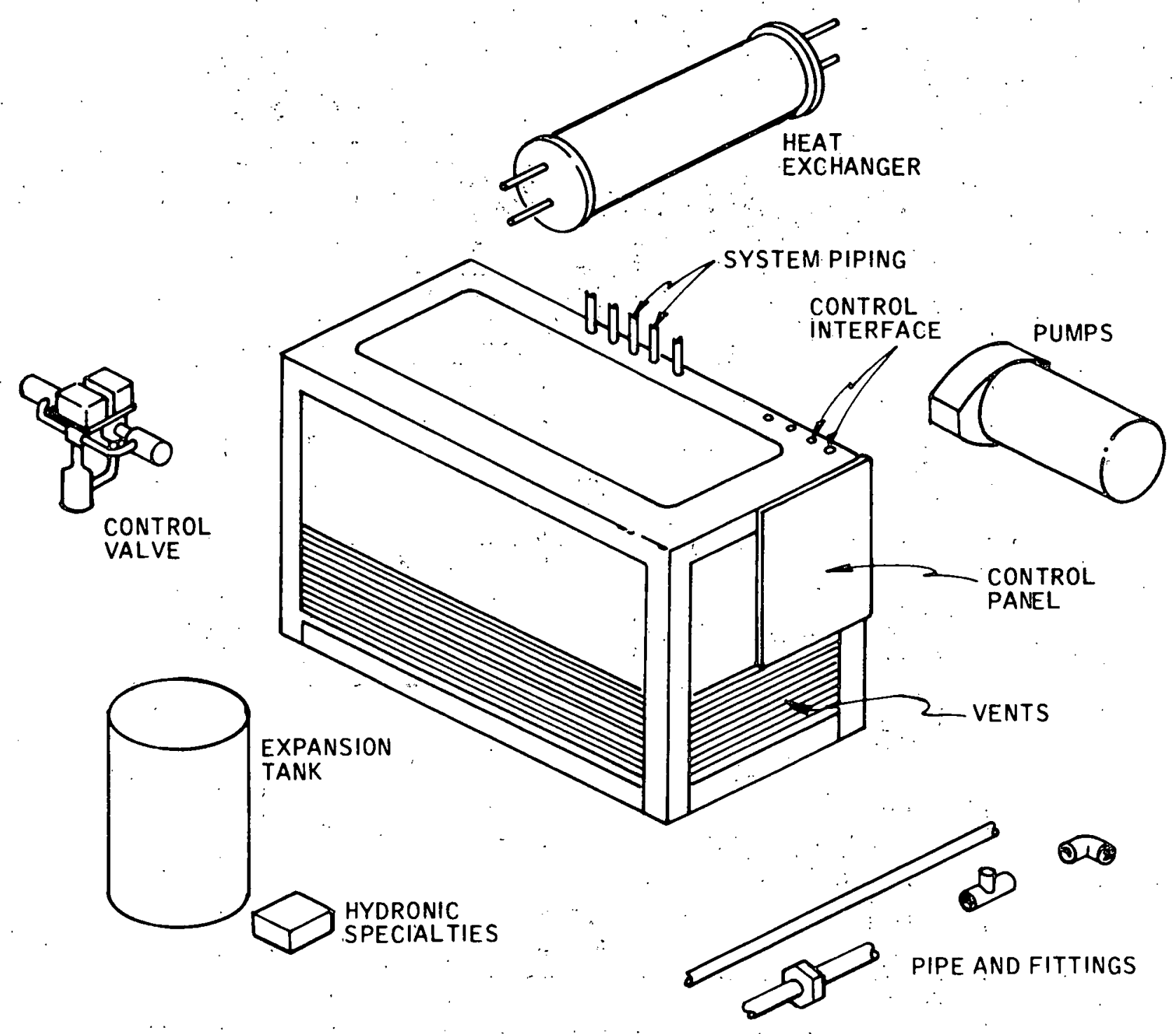

FIGURE 4-20. Energy T ransport Module 


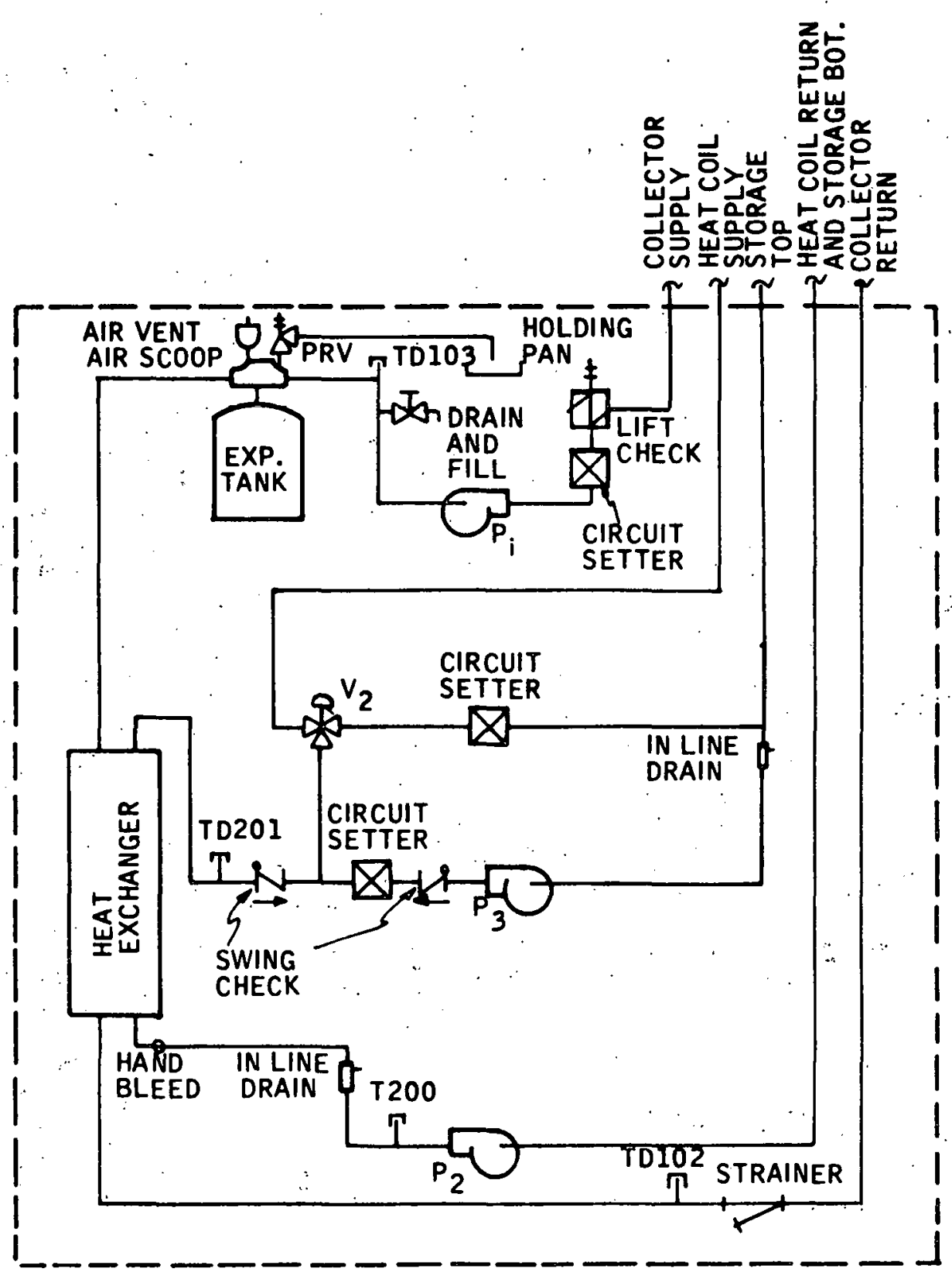

FIGURE 4-21. ETM Component/Plumbing Schematic 


\section{Shipping \& Installation}

4) ETM must possess sufficient structural strength to sustain (undamaged) transport to the installation site.

5) Weight to be consistent with residential installations requiring no more than two men to handle the module.

6) Outside dimensions such that modules can be placed inside buildings without special entrance requirements.

7) The number of plumbing and electrical installation connections are kept to a minimum and they must be readily accessible.

\section{Operation}

8) All serviceable components are field removable without disassembly of the other module components.

9). Module internal temperatures are held to a level consistent with the service requirements of the equipment

10) . Noise levels are held to a reasonable level consistent with residential installations

11) System can be leak checked and its operation checked prior to shipment.

\section{Design Tradeoffs}

The final ETM design evolved after investigating some fifteen component arrangements and holding numerous design review'meetings with solar system engineers, plumbers, and mechanical/cabinet designers. It was determined that horizontally-mounted pumps and heat exchangers provided optimum performance and ease of mounting. Since cabinet size is critical, a diaphram expansion tank is preferred over a standard air cushion expansion tank because it can be physically smaller while providing the same function. Also, 
a diaphragm-type tank eliminates the expansion tank. "water logging" problem. Ease of installing the ETM on site and its adaptability into various system layouts were studied; the preferred cabinet design was one with all external connections through the same area of the cabinet top.

These component and installation criteria, a continuous effort to avoid air entrapment in plumbing lines, and attention paid to the previously mentioned design goals were considered during investigation of various ETM component orientations and plumbing arrangements. Finally, using the resulting basic ETM design, cabinet compactness was traded off against accessibility to, and function of, its components.

To determine the best insulating technique, foams, batting, individually insulated piping, and loose fill insulation were investigated. Fire, toxicity, and difficult removal are foam characteristics that excluded its use for the small quantity of demonstration modules, though some special types of foam have potential in large quantity application. Use of batting and individually insulating piping requires a considerable amount of labor time. Final selection was the use of loose wool and some standard piping insulation.

\section{Final Energy Transport Module Design}

Characteristics of the ETM.design, based on the above tradeoffs and goals, are described below:

\section{General}

1

\& 2) The ETM will provide a functional, efficient interface subsystem for the two systems designed in this program and also for a majority of other residential solar heating applications. 
3) The fifty-seven Interim Performance Criteria requirements for Solar Energy Transport subsystems, which directly affect the ETM, have been analyzed and are met. Some requirements are discussed in this study; others (such as thermal expansion of fluids and piping, relief valves and vents; fire standards, and component design lifetimes) are discussed in the verification report.

\section{Shipping and Installation}

4) The cabinet will be fabricated with 12-gauge formed steel corner framing with welded joints and lighter-weight removable panels. The cabinet has been designed to withstand shipping loads (in its operational orientation) and handling during installation (cabinet will be handled using the side opposite the solar control box as the base).

5) ETM shipping and installation weight is about 200 pounds for components and about 150 pounds for the cabinet; or 350 pounds total.

6) The ETM external dimensions are: 28 inches wide, 32 inches high, and 45 inches long (this 45 inches would be along the wall in a usual installation). In its handling orientation, it can be placed on a dolly, resulting in ample clearance between doorways and the 28 -inch-wide cabinet.

7) The basic installation procedure consists of setting the ETM in place and connecting the plumbing and external control wiring to it from the other subsystems. (The ETM is internally pre-wired.) The above actions and all others required for system startup are performed external to the cabinet or inside the cabinet through one of the removable access panels.

\section{Operation}

8) Serviceable components, both hydronic and electrical, have been made readily accessible due to internal plumbing arrangement, cabinet design (note that the Solar Control Box is externally mounted with its hinged door 
exposed), insulation techniques, and removable access panels. The extent of access can also accommodate nonroutine work, such as on-site installation of Site Data Acquisition sensors or the repair/removal of a plumbing segment or component. Space adjacent to electric motors, removable union-type fittings for each pump, and components with replaceable elements allow for required servicing.

9) The insulation technique selected for the ETM was based on the following criteria, which must be simultaneously satisfied:

a) An allowable upper temperature limit $\left(110-125^{\circ} \mathrm{F}\right)$ for interior ambient air surrounding electric motors.

b) Cabinet exterior temperature less than $140^{\circ} \mathrm{F}$.

c) Compared to the overall house cooling load, the uncontrolled heat loss from the ETM must be minimal during summer months.

d) System efficiency due to ETM heat loss should be negligible. To accomplish the above, component arrangement was such that those requiring insulation and minimal servicing (such as the heat exchanger and long pipe runs) would be separated from those requiring free-flow, low-temperature ambient air and some servicing (such as pump and diverting valve motors). The heat exchanger and majority of long pipe runs were located in the upper portion of the cabinet. A 44-inch by 28-inch steel divider secured under the heat exchanger totally encloses this upper. portion, which is then filled with loose insulation. The air temperature in the lower portion is kept below the design maximum by insulating straight pipe runs, providing louvers in the side panels, and allowing natural convection and air movement caused by pump motors to vent out any excess heat. Additionally, with this insulation technique, the criterion of $140^{\circ} \mathrm{F}$ cabinet temperature, overall system efficiency, and negligible uncontrolled heat loss from the ETM were satisfied. 
10) The noise level produced by the ETM in operation is low, due to:

a) Pump selection (noise-pertinent criteria was a well-designed, quiet operating, $1750 \mathrm{rpm}$, elastically-coupled pump and motor).

b) Design flow rate maintains three (3) feet per second flow through plumbing, which is less than ASHRAE's recommended rate of 4 feet per second.

c) Water hammer within module is minimized by use of a slow-operating diverting-type motorized valve.

11) All modules will be tested for leaks, functional and potential shipping problems. Suitable draining and filling procedures are developed, and operation and installation procedures are delineated.

\section{Heat Exchanger Analysis}

The method used to determine the overall heat exchanger dimensions and design parameters is primarily the method of Kays and London. The following general assumptions are made in the calculations:

- The heat exchanger is considered adiabatic

- Fluid flow is steady with constant properties

- The overall heat conductance is considered to be constant for given conditions.

- A counterflow configuration is used

- The process requirements at design conditions are determined by the solar system predicted performance.

\section{Physical Description}

The geometrical and physical characteristics of the heat exchanger are shown in Figure 4-22. The heated fluid flows in the spirally formed coils 


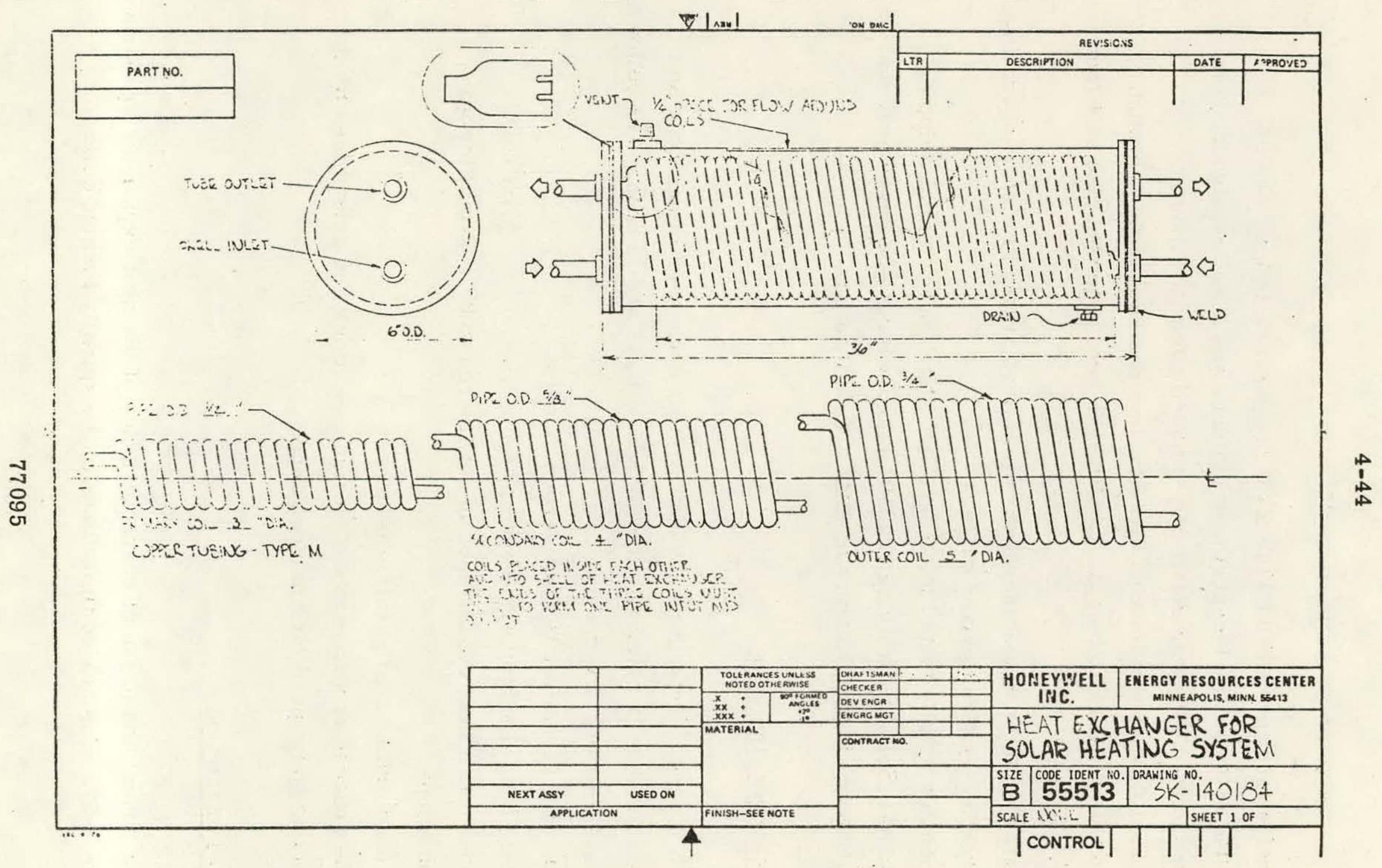

FIGURE 4-22. Heat Exchanger 
completely immersed in the heating fluid on the shell side. Heat transfer intensification of the copper tubing (type $M$ ) is produced by additional generation of turbulence on the inner and outer surface of the tube. Basically, two types of enhanced surfaces are considered:

- Circular smooth tube with bilateral heat transfer intensification. This corrugating style is a single-start helical shape performed without decreasing the wall thickness or increasing the outside diameter of the tube.

- Spirally fluted tubing that increases the radial velocity components. The associated radial mass flow increases the internal film coefficient.

\section{Performance Predictions}

Based on solar system output, the following design conditions were selected for the heat exchanger performance requirements:

- Collector fluid temperature drop of $10^{\circ} \mathrm{F}$

- Collector fluid flow rate of 12 gpm.

Thus the total heat transfer through the heat exchanger amounts to 55,000 $\mathrm{Btu} / \mathrm{Hr}$. With a heated fluid flow rate of $8 \mathrm{gpm}$ at $120^{\circ} \mathrm{F}$. and a collector outlet temperature of $140^{\circ} \mathrm{F}$, the heat exchanger effectiveness is expected to be approximately 0.70. This reduces to a predicted overall heat transfer.' coefficient (UA) of $7000 \mathrm{Btu} / \mathrm{Hr}{ }^{\circ} \mathrm{F}$ resulting from the individual heat transfer coefficients. Pressure drop correlations based on manufacturers data show an increase of 2.4 times the pressure drop for an equivalent plain tube heat exchanger. But the overall pressure drop on the collector fluid is expected to be-maintained close to $4.0 \mathrm{psi}$. 


\section{Work Planned for Next Quarter}

- Cabinet fabrication and construction of ËTM.

- Testing of ETM

- Analysis and preliminary design of transport subsystem for MFR application.

CONTROL SUBSYSTEM

Work : Accomplished During Quarter

Heating Only Systems, Single-Family Residence - - Detailed design of the control subsystems for the single-family residence baseline solar . heating system has been completed. This design was utilized in preparing the installation drawings and site mechanical drawings for the Stillwater, Minnesota, site. Slight modifications will be necessary for the Newcastle, Pennsylvania, site.

Heating and Cooling Systems - - Detailed design of the control subsystems for the heating and cooling:systems has been deferred until development of the control systems of the Rankine. Cycle units have been further developed.

Problem Areas and Solutions

Heating Only Systems, Single-Family Residence -- The collector plate control sensor location was determined by a testing program. Results of the testing led to further testing, which is now underway to determine sensor performance over a wide range of operation. 
Heating and Cooling Systems -- The above testing w ill be applicable to heating and cooling systems and will be utilized in the detailed design of control subsystems.

\section{Plans for Next Quarter}

Heating Only Systems, Single-Family Residence - Detailed design of the control subsystem for the Newcastle, Pennsylvania, site will be completed by late July 1977 .

Heating and Cooling Systems - Analys is and design work progress will not impact the time schedule of the program.

COOLING

Residential Cooling Subsystem

Rankine_Cycle - - The design has adyanced to the assembly stage with ordered parts in house. Both frame assemblies arefabricated. Plumbing the components of the first unit is in progress.

The control box is assembled, and wiring is complete for the first unit. The feed pump-boost pump test passed the 2,500-hour mark at the end of this quarter. It will be completêd $(3,000$ hours $)$ before the end of July: The performance is completely normal with no detrimental effect of the R-113 on the components. 
The 3-ton turbo-gearbox test was started near the end of the quarter. Gears ground to reduce the noise level were installed in the gearbox, which is driven by the turbine designed for the 3-ton unit. The original 3 -ton unit designed for the van is used as the boiler-condenser unit. The turbo-gearbox system was tuned up to show performance equal to that presented in the original design. The turbine efficiency is above $72 \%$, and the gearbox loss is about $0.1 \mathrm{hp}$. The mist lubrication system based on a freon-oil pool in the demister appears to be operating extremely well.

Air Conditioning - The quarterly objectives include:

1. Final selection of all subsystem components.

2. Complete the purchased component acquisition process.

3. Obtain in house all purchased pairt components?

4. Fabricate sheet metal components sufficient for two units.

5. Assemble unit cabinetry and all refrigeration subsystem.

6. Test Unit No. 1 in Lennox Environmental Test Room.

7. Complete all drawings, both detailed and assembly, for unit cabinetry and plumbing.

8. Begin work on Installation, Operation; and Maintenance Manuals.

9. Begin work on Spare Parts List.

All program objectives for this report period have been met or exceeded except for the following items:

- Item 7 - New completion date for drawings, July 15, 1977:

- Item 9. - Spare Parts List to begin directly following unit drawing completion.

Two units have been fabricated, including sheet metal cabinetry and refrigeration subsystem. Unit No. 1 has been tested in the Lennox Test Facility.

A test program and pictures of the test setup are included in the Appendix of this report. Test results are now under evaluation and will be forwarded during the next reporting period. 
Both units have been prepared for and are now awaiting painting.

Drafting - All assembly drawings, sheet metal and plumbing have been completed. Detailed drawings of sheet metal parts have been completed. Plumbing detailed drawings are currently in process.

\section{Multi-Family and Commercial Cooling Subsystem}

Rankine Cycle - - Final detailed layouts of the components and plumbing are in progress. A $1 / 4$ scale model of the unit has been constructed to coordinate the Lennox and Barber-Nichols interface. The control system schematic has been comp?.eted. All major components have been ordered.

Air Conditioning - - Structural design and components final layouts are complete. Purchased orders for all components including $20 \mathrm{Hp}$ motor have been completed. Top and side panel drawings are complete.

Fabrication of the first base frame and mounting for the compressor motor, gearbox and turbine are complete. This unit will be shipped to Barber-Nichols for assembly of the first complete system. First draft of the IOM Manidals is complete.

Production of units 2 through 8 will be conducted at the Lennox Stuttgart plant.

\section{Plans for Next Quarter}

Rankine Cycle - - Complete assembly and initiate testing of the first $21 / 2$-ton subsystem. Initiate the combined $(A / C-R / C)$ assembly of the second $21 / 2$-ton subsystem. 
Complete fabrication of all components for the eight 23 -ton systems. Complete the combined assembly of the first unit, and initiate the system testing.

Air Conditioning $\because$ Complete all the final detailed drawings for the plumbing of the residential subsystem.

Complete the testing and shipment of residential unit Number 1 to BarberNichols for combined assembly.

Ship residential unit Number 2 to Carrollton, Texas, for further testing.

Ship the 23-ton frame, chiller, compressor and condenser to BarberNichols for combined assembly.

Complete all final drawings, IOM Manuals and spare parts lists. 


\section{SECTION 5}

SITE ACTIVITY

\section{SFR HEATING - STILLWATER, MINNESOTA}

Extensive site improvement activity has been proposed and initiated to accommodate the solar heating system at Stillwater, Minnesota. Building additions and renovations, energy conservation modifications, landscaping changes, and conventional heating changes have been examined.

\section{General Site Work}

Extensive site work has been planned.at the SFR Stillwater, Minnesota, solar heating site. The following is a summary of proposed site development work.

- A new garage will bc added to the existing structure, and it will interface with the present tuck-under garage. The old garage will house the solar storage tank, energy transport module, data acquisition equipment, and will provide additional space for the residencé.

- The conventional heating system will be changed from an oil source to natural gas. Tunneling will be done under the adjacent highway to connect to the existing gas line 800 to 1000 feet from the residence. All oil furnace related equipment shall be removed from the residence.

- Site landscaping will be done to remove any collector shading hazards. Existing trees on the east side of the residence, which 
would cause a shading problem for the collector field, shall be removed. No aesthetic degradation is expected for the residence.

\section{Collector Field Support Structure}

The support structure for the entire collector field will be incorporated as an integral part of the residential building. A special lean-to type of structure, closed off at both ends, shall be constructed. The shingled top surface will be joined to both the south-facing main wall of the house and the roof of the new garage.

All collector-to-beader interconnections shall be completely sealed from the environment by fiberglass flashing and silicone caulking compound. A spring clip inserted in the space above the collector-to-collector interconnections shall seal these collector field joints. In addition, drainage is still provided at all of the connections as a backup to prevent any moisture accumulation.

The bottom end of the collector structure shall be anchored to concrete footings. The structure extends slightly over the footing ridge, and juts 12 to 15 inches above the ground. Such placement provides good water drainage from the structure and sufficient space for removal of any snow accumulation during winter months.

Site Energy Cónservation Modifications

Initial calculations to determine sensible heating load and load due to infiltration were performed for the William O'Brien site as it originally existed. Calculation results showed the following conditions: 


$$
\begin{aligned}
& \mathrm{UA}=750 \mathrm{BUT} / \mathrm{Hr} .-{ }^{\mathrm{O}_{\mathrm{F}}} \text { (approx.) } \\
& \text { Infiltration }=125 \mathrm{cfm} \text { (approx.) }
\end{aligned}
$$

Simulation heating load analysis showed that, with 28 collector modules (504 sq. ft.), less than a $30 \%$ solar contribution could be expected. Therefore, energy conservation measures were needed to make the site feasible for solar assisted heating.

The following energy conserving measures will be made at the retrofit solar heating site.

1. N.ll windows on the house are single glaze but have storm windows added during the heating season. Due to the age of the structure $(20 \pm$ years), weatherstripping will be done on all windows exposed to outdoor conditions.

2. The attic presently has only 4 inches of loose fill insulation. Six more inches of insulation will be added in the attic.

3. The air duct in the present tuck-under garage, an unheated ipace, is uninsulated. Fiberglass blanket insulation ( 1 inch l.hick) will be provided.

4. The walls of the exposed basement consist of 12 inch thick concrete block and are a large contributor to the total sensible heat loss from the building. This interior wall envelope will have $i^{1 / 2}$ inch styrofoam insulation and $5 / 8$ inch gypsum board added. 
5. The main building walls have only 2 inches of fiberglass insulation; more insulation should be added. Such a renovation would be quite costly, and therefore these' walls will be left in their existing condition.

6.: The new addition to the house will be a garage; the present tuck-under garage will be modified to house solar equipment. The present garage door will be closed with concrete blocks, and a window will be installed in its place. Also, two of the presently exposed walls will have $3 / 4$ inch styrofoam insulation added, and the north facing wall will be finished with $5 / 8$ inch gypsum board. This space will remain unheated.

7. $\because$ The collector stand will be an integral part of the south facing residential wall.' Both, ends of the structure shall be closed off, and therefore, it will serve as a buffer shielding a large portion of the south wall of the house from environmental conditions.

With these proposed changes, a substantial decrease in sensible heat loss and also a decrease in infiltration losses was obtained. Calculations show the following conditions:

$$
\begin{aligned}
& \mathrm{UA}=460 \mathrm{BUT} / \mathrm{hr} \cdot-{ }^{\mathrm{O}} \mathrm{F} \text { (approx.) } \\
& \text { Infiltration }=110 \mathrm{cfm} \text { (approx.) }
\end{aligned}
$$

The first parameter was reduced by $39 \%$ and the latter by $12 \%$ from the values for the original building prior to the energy conservation innovations. 
SFR HEATING - NEWCASTLE, PENNSYLVANIA, SITE

A coordination meeting was held at the site in mid-June, 1977. Attendees included the Newcastle Redevelopment Authority (site owner), the architect, NASA/MSFC," and Honeywell ERC. As a result of this meeting; a revised time schedule for this site was prepared. This time schedule is shown in. Figure 3-2 in Section 3 of this document.

Design activity for this site continues with preliminary architectural design work by the architect. Emphasis has been given to integrating the solar heating systems aesthetically into the architectural concept and the utilization of minimum energy concepts.

The site does not have natural gas available; thus the baseline auxiliary space heating subsystem (forced air gas furnace) can not be used. A conventional (non-solar assisted) air source electric heat pump with auxiliary electric resistance heater will be utilized as the auxiliary space heating subsystem for this site.

The preliminary architectural design is finalized to the point that a $21 / 2$ ton heat pump unit has been selected. Testing of the unit blower has begun, and the results will be used in the preparation of installation drawings. Design work for all other subsystems is almost complete with remaining tasks to be completed in the near future. 
Plans for Next Quarter

Architectural working drawings will be completed by the first week in August, 19.77, and will be released for bidding by local contractors.: This will provide several fixed price bids for evaluation at the Prototype Design Review., which is scheduled for August 24, 1977.

MFR HEATING \& COOLING - LAWRENCE, KANSAS (KU)

A system introduction and kickoff meeting was held at KU on June 21: "A document describing the system and the suggested interface was presented to KU. The KU staff is conducting a preliminary design review looking at' collector placements, building interface, etc., in preparation for the site/system interface meeting. A second coordination meeting is set for July 21. Based on the results of this meeting, a date will be set for the interface meeting in August. 


$$
6-1
$$

\section{SECTION 6}

\section{DATA SUBMISSIONS}

The attached ledger includes all contractual data items to be delivered. This latest revision (No. 10) now only shows the plan for activities scheduled between July 1, 1977, and July 30, 1978; all items are current. 


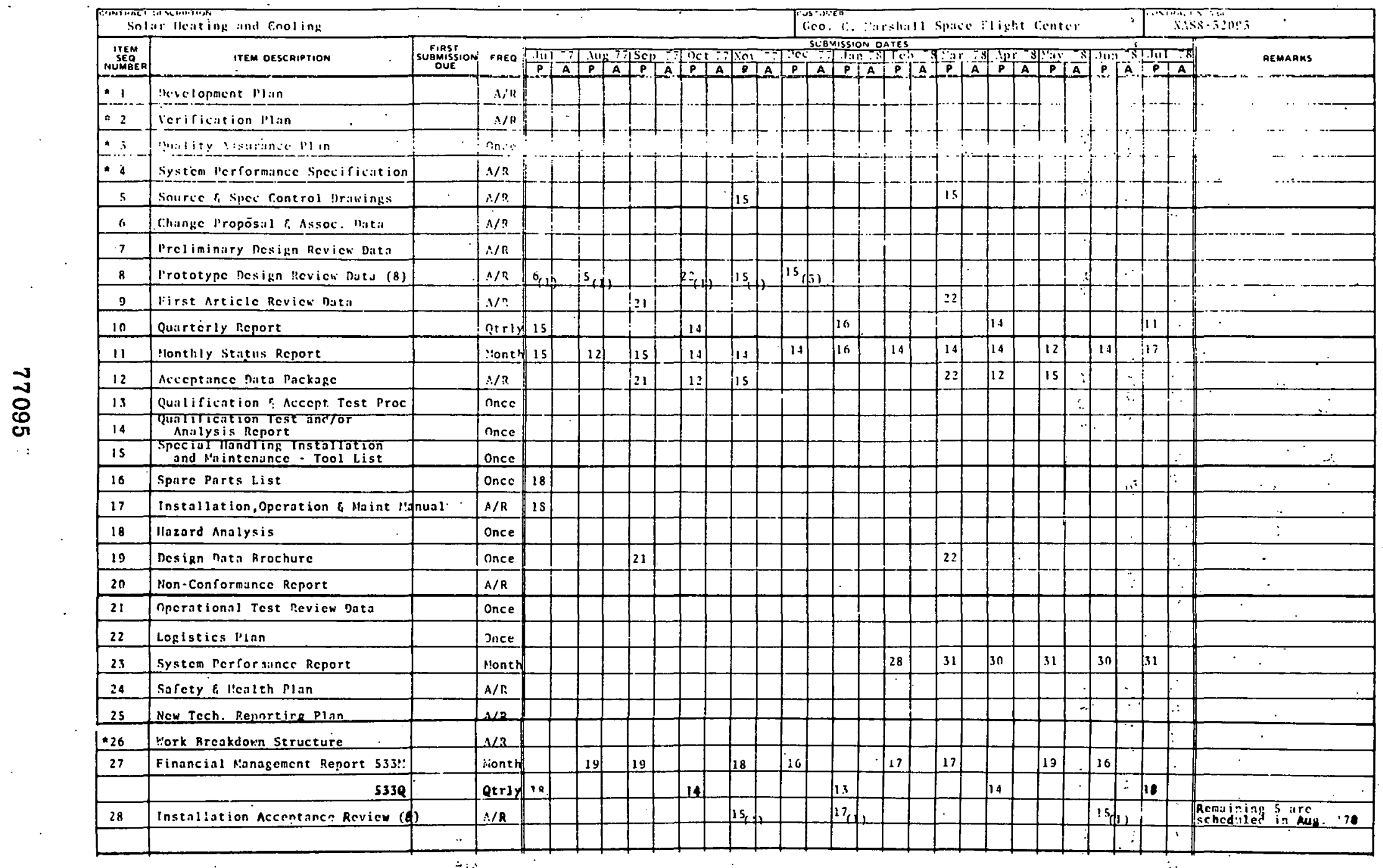




\section{APPENDIX}

TEST PROGRAM - NASA -404 RESIDENTIAL COOLING SUBSYSTEM

\section{OBJECTIVE}

To fulfill the requirements of the NASA-404 contract, the following tests must be completed. The objectives of this test program are as follows:

- Evaluate subsystem components.

- Verify subsystem performance criteria.

- Evaluate total subsystem during off-design conditions.

\section{EQUIPMENT}

The following components will be under test for this program:

Condensing Unit

Evaporator

Expansion Valve

Line Sct

$$
\text { RHS1 - 311V-1A }
$$$$
\text { C10-65. }
$$

SFE-2 1/2 - FCP60 - BP $/ 30$

25 Feet, $11 / 8^{\prime \prime}$ Suction, $1 / 2$ " Liquid

TEST APPARATUS

Cooling Tower Similator

This test apparatus consists of the following components:

Centrifugal Water Pump

3-Way Mixing Valve

Valve Control Linkage

Valve Control Thermostat

Storage Tank

*Flowmeter
Bell \& Gossèt 1522-17T-1

Honeywell Q618A 1032

Hôneywell MJ45A 1009

Honeywell T991A 2036

Water Tank with Electric Elements

Coil Test Stand

* Flowmeter must have float change for flow rate during these tests. 
Assemble the components per the piping schematic as presented in Figure A-1.

Refrigerant Flow rater

A flow rater shall be installed in the system liquid line.

Electrical Measurement Devices and Motor Speed

A voltmeter shall be utilized to check voltage input at the motor leads. (Voltage to be $230 \mathrm{~V}$ ).

A watt-hour meter shall be installed in the motor circuit to verify test console electrical energy input.

During all test data recording points, motor and compressor speed (rpm) shall be monitored and recorded. Utilize a strobe light for this purpose. The strobe mist be calibrated at least once a day or whenever it has been restarted after a shut-down period.

\section{Refrigeration Subsystem Temperatures}

The following thermocouples mist be installed on the system prior to testing:

Suction at Compressor

Discharge at Compressor

Liquid at Condenser Outlet

Liquid at Flow rater

Liquid at Entrance of Expansion Valve

Circuit Outlets at Evaporator (Individual)

Suction at Evaporator (common out)

Cooling Water Entering Unit 
Refrigeration Subsystem Temperatures (continued)

Cooling Water Exiting Unit

Unit Interior Ambient

Liquid at Exit of Liquid to Suction Heat-X

Refrigerant Subsystem Pressures

The following system pressures must be sampled:

Suction at: Compressor

Discharge at Compressor

Crankcase of Compressor

Liquid at Condenser Outlet

Suction at Evaporator Outlet

Suction "upstream" of Accumulator

Suction "downstream" of Accumulator

Cooling Water Supply

Cooling Water Return

System Electrical

System utilizes calibrated motor number RR-22. Operäé motor at $230 \mathrm{~V}, 3 \varnothing$.

\section{System Charge}

The NASA-404 system uses Refrigerant 12. Compressor speed must be $810 \mathrm{rpm} \pm 10$ while under standard load conditions. Charge system to $5^{\circ}$ subcooling measured from the discharge pressure at the compressor and the liquid temperature at the condenser outlet for the following conditions:

Entering Water Temperature

Water Hlowrate

Indoor Air Volume

Entering Air Temperature $85^{\circ}$

15 GPM (As a starting point)

1125 CFM (As a starting point) $80^{\circ} \mathrm{db} / 67^{\circ} \mathrm{wb}$ 


\section{TEST POINTS}

\section{Phase I - Standard ARI Rating Conditions}

Entering Water Temp. $-85^{\circ} \mathrm{F}$; Leaving Water Temp. $-95^{\circ} \mathrm{F}$;

Water Flowrate-Adjusted to meet water temperature conditions;

Indoor Entering Air Temp. $-80^{\circ} \mathrm{db} / 67^{\circ} \mathrm{wb}$; Indoor Air

Volume - Check with Engineer; Ref: ARI Standard 210-75.

\section{Phase II - Maximum Operation Conditions Under Voltage (Change motor)}

Entering Water Temp. $-90^{\circ} \mathrm{F}$; Leaving Water. $-100^{\circ} \mathrm{F}$;

Ambient Surrounding Unit - $115^{\circ} \mathrm{F}$; Water Flowrate - Adjusted

to meet entering and leaving water conditions; Indoor Air

Temp. - $95^{\circ} \mathrm{db} / 71^{\circ} \mathrm{wb}$; Indoor Air Volume - As established

during Phase I; Under voltage - 207 V; Ref: ARI Standard 210-75.

\section{Phase III - Minimum Ope rating Conditions}

Leaving Water Temp. - 70 F; Flowrate - As established during Phase I; Indoor Air Temp. $67^{\circ} \mathrm{db} / 57^{\circ} \mathrm{wb}$; Indoor Air Volume - As established during Phase I; Ref: ARI Standard 210-75. 
Phase IV - General Operating Performance

\begin{tabular}{|c|c|c|c|c|}
\hline $\begin{array}{c}\text { Test } \\
\text { Point } \\
\text { No. } \\
\end{array}$ & $\begin{array}{c}\text { Entering } \\
\text { Water } \\
\text { Temp. , }{ }_{\mathrm{F}} \\
\end{array}$ & $\begin{array}{l}\text { Entering } \\
\text { Water } \\
\text { Flow, GPM } \\
\end{array}$ & $\begin{array}{l}\text { Entering } \\
\text { Indoof Air } \\
\text { Temp. } \mathrm{F}(\mathrm{db} / \mathrm{wb})\end{array}$ & $\begin{array}{l}\text { Entering } \\
\text { Indoor Air } \\
\text { Flow, CFM } \\
\end{array}$ \\
\hline 1 & $85^{\circ}$ & 15.0 & $80^{\circ} / 67^{\circ}$ & As per Phase I \\
\hline 2 & $85^{\circ}$ & 12.5 & $80^{\circ} / 67^{\circ}$ & As per Phase I \\
\hline 3 & $85^{\circ}$ & 10.0 & $80^{\circ} / 67^{\circ}$ & As per Phase I \\
\hline 4 & $85^{\circ}$ & 7.5 & $80^{\circ} / 67^{\circ}$ & As per Phase I \\
\hline 5 & $85^{\circ}$ & (Check with Eng'r) & $80^{\circ} / 71^{\circ}$ & As per Phase I \\
\hline 6 & $85^{\circ}$ & (As per point 5) & $80^{\circ} / 63^{\circ}$ & As per Phase I \\
\hline 7 & $95^{\circ}$ & (As per point 5 ) & $80^{\circ} / 67^{\circ}$ & As per Phase I \\
\hline 8 & $75^{\circ}$ & (As per point 5 ) & $80^{\circ} / 67^{\circ}$ & As per Phase I \\
\hline 9 & $65^{\circ}$ & (As per point 5 ) & $80^{\circ} / 67^{\circ}$ & As per Phase I \\
\hline
\end{tabular}

REFRIGERANT 12 TABLES

Please find attached to this test program a partial copy of the Refrigerant Tables for $\mathrm{R}-12$. 
$A-6$

AMENDMENT NO. 1

TEST PROGRAM - NASA-404 RESIDENTIAL COOLING SUBSYSTEM

The following changes milst be added to the master test program:

EQUIPMENT

Change: Evaporator from a C10-65 to C5-920.

\section{TEST APPARATUS}

System Charge -

Charge to $5^{\circ}$ subcooling measured from liquid pressure at condenser outlet and the liquid temperature at the outlet of the liquid to suctiun heat exchanger.

\section{TEST POINTS}

Phase II

Add: Maximum Operating Conditions, Overvoltage Entering Water Temp. $-90^{\circ} \mathrm{F}$; Leaving Water Temp. $-100^{\circ} \mathrm{F}$; Ambient Surrounding Unit - $115^{\circ} \mathrm{F}$; Water Flowrate Adjusted to meet entering and leaving water conditions; Indoor air temp. $-95^{\circ} \mathrm{db} / 71^{\circ} \mathrm{wb}$; Indoor Air Volume As established during Phase I; Ref: ARI Standard 210-75. 


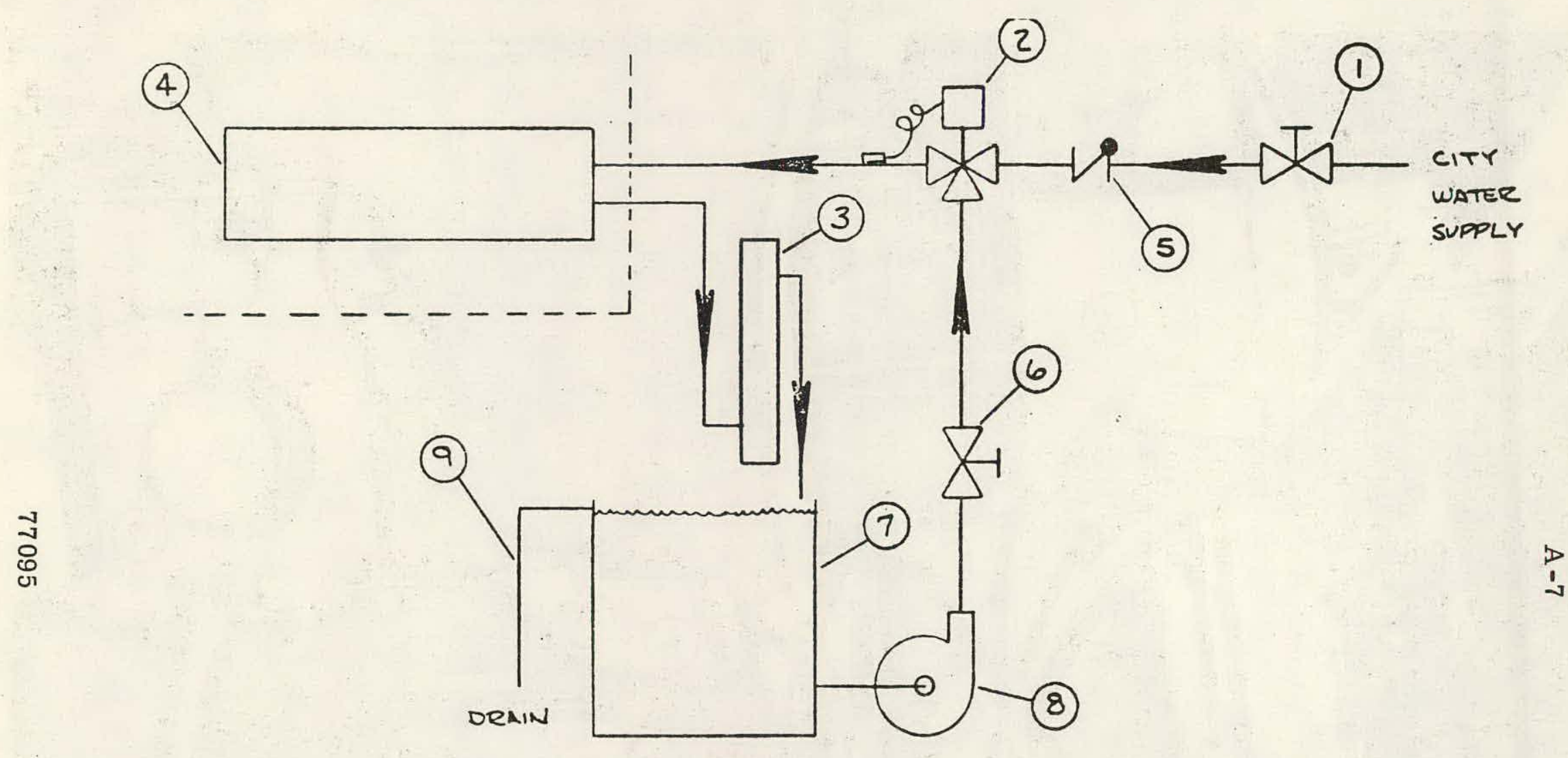

\begin{tabular}{|c|l|}
\hline ITEM & DESCRIPTION \\
\hline 1 & HAND VALVE \\
\hline 2 & THREE-WAY VALVE \\
\hline 3 & FLOWRATER \\
\hline 4 & A/C CONDENSER \\
\hline 5 & CH ICK VALVE \\
\hline 6 & HAND VALUE \\
\hline
\end{tabular}

\begin{tabular}{|c|l|}
\hline TEM & DESCRIP TION \\
\hline 7 & HOLDING TANK \\
\hline 8 & WATER PUMP \\
\hline 9 & OVER FLON TUBE \\
\hline & \\
\hline & \\
\hline & \\
\hline
\end{tabular}

Figure A-1. Cooling Tower Simulator 


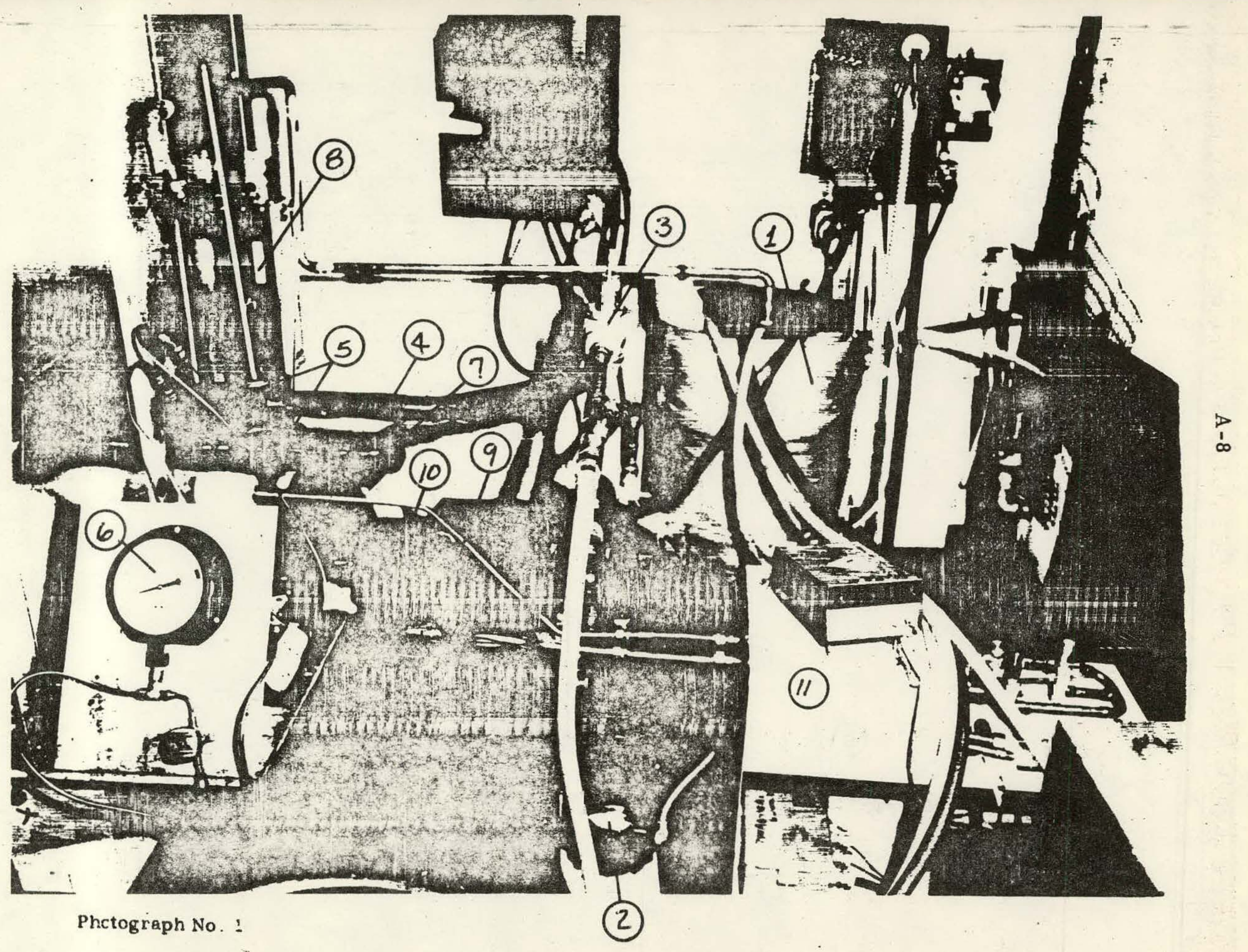


NASA -404

Residential Single Family Cooling Subsystem

Test Set-up

Item Description for Photograph No. 1

1. Water catch basin.

2. Supply water pump.

3. Mixing Valve.

4. Supply water line.

5. Thermometer wells.

6. System water pressure drop gauge.

7. Return water line.

8. Water flowmeter.

9. Refrigerant liquid line.

10. Refrigerant suction line.

11. Refrigerant flowmeter 


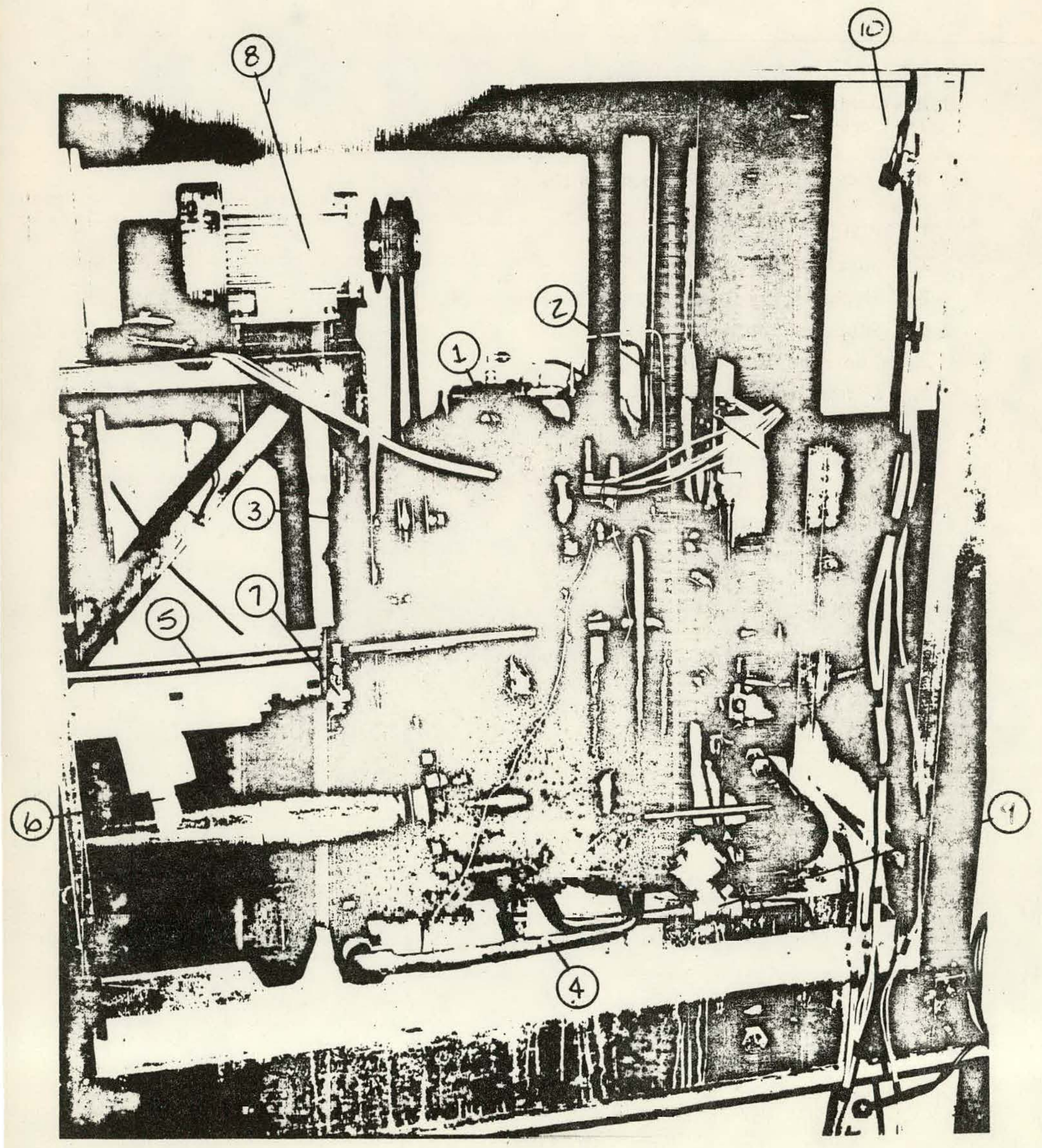

Photograph No. 2 
NASA -404

Residential Single Family Cooling Subsystem

Test Set-up

Item Description For Photograph No. 2

1. Refrigerant compressor.

2. Compressor safety dual pressure switch.

3. Liquid to suction heat exchanger.

4. Refrigerant liquid line.

5. Refrigerant discharge line.

6. Water cooled condenser.

7. Condenser refrigerant pressure relief valve.

8. Calibrated electric motor.

9. Condenser water drain valve.

10. Control box. 


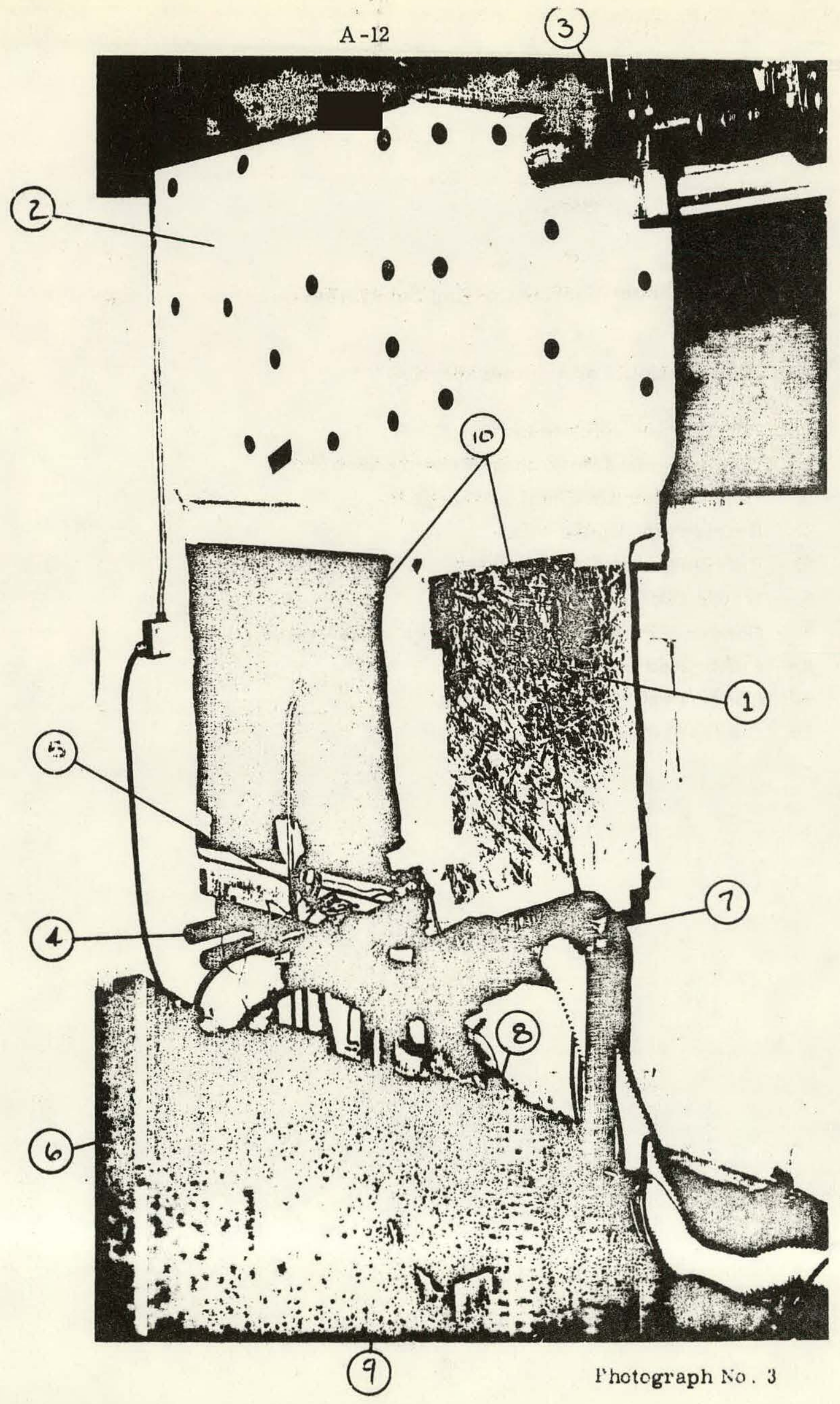


NASA -404

Residential Single Family Cooling Subsystem

Test Set-up

Item Description for Photograph No. 3

1. Evaporator enclosure.

2. Outlet air duct system.

3. Supply air sampler.

4. Return air sampler.

5. Thermostatic expansion valve.

6. Refrigerant liquid line.

7. Refrigerant suction line.

8. Thermocouple bundle.

9. Condensate drain line.

10. Air pressure taps. 